Geomorphology

Elsevier Editorial System(tm) for

Manuscript Draft

Manuscript Number: GEOMOR-3738R1

Title: EROSION IN MEDITERRANEAN LANDSCAPES: CHANGES AND FUTURE CHALLENGES

Article Type: Review Article

Keywords: Erosion; Badlands; Land use changes; Intensification; Land abandonment; Mediterranean landscapes

Corresponding Author: Dr. Jose-Maria Garcia Ruiz, PhD Doctor

Corresponding Author's Institution: Instituto Pirenaico de Ecologia, CSIC

First Author: Jose-Maria Garcia Ruiz

Order of Authors: Jose-Maria Garcia Ruiz; Estela Nadal-Romero; Noemí Lana-Renault; Santiago Beguería

Abstract: Intense erosion processes are widespread in the Mediterranean region, and include sheet wash erosion, rilling, gullying, shallow landsliding, and the development of large and active badlands in both subhumid and semi-arid areas. This review analyses the main environmental and human features related to soil erosion processes, and the main factors that explain the extreme variability of factors influencing soil erosion, particularly recent land use changes. The importance of erosion in the Mediterranean is related to the long history of human activity in a region characterized by low levels of annual precipitation, the occurrence of intense rainstorms and long-lasting droughts, high evapotranspiration, the presence of steep slopes and the occurrence of recent tectonic activity, together with the recurrent use of fire, overgrazing and farming. These factors have resulted in a complex landscape in which intensification and abandonment, wealth and poverty can co-exist. The changing conditions of national and international markets and the evolution of population pressure are now the main drivers explaining land use changes, including farmland abandonment in mountain areas, the expansion of some subsidized crops to marginal lands, and the development of new terraces affected by landslides and intense soil erosion during extreme rainstorm events. The occurrence of human-related forest fires affecting thousands of hectares each year is an increasing problem in both the northern and southern areas of the Mediterranean basin. Here, we highlight the rise of new scientific challenges in controlling the negative consequences of soil erosion in the Mediterranean region: (i) to reduce the effects and extent of forest fires, and restructure the spatial organization of abandoned landscapes; (ii) to provide guidance for making EU agricultural policy more adapted to the complexity and fragility of Mediterranean environments; (iii) to develop field methods and models to improve the identification of runoff and sediment contributing areas; (iv) to contribute to the conservation 
of landscapes (i.e. bench-terraced fields) having high cultural and productivity values; ( $v$ ) to improve knowledge of the hydrological and geomorphological functioning of badlands, with the aim of reducing sediment yield and accessibility; ( $v i$ ) to better understand the effect of climate change on soil erosion in the Mediterranean region; and (vii) to improve quantitative information on long-term soil erosion. 


\section{COVER LETTER}

Paper: Erosion in Mediterranean landscapes: Changes and future challenges

Authors: José M. García-Ruiz, Estela Nadal-Romero, Noemí Lana-Renault, Santiago Beguería

Dear colleague,

We greatly acknowledge the work done by two referees, and the many corrections introduced in the text by the Editor of Geomorphology, Professor Takashi Oguchi. We have accepted and corrected all the suggestions from the referees and the Editor. Nevertheless, the second of the reviewers recommended adding a table summary to quantify the erosion problem. We speak in the text about the difficulties for accepting erosion rates, given the different methods and scales and the extreme variability of the erosion values, and for this reason we prepared the Figure 8, where both the importance of soil erosion and the variability of erosion in the Mediterranean region are considered. We look forward to hearing from you,

José M. García-Ruiz

Research Professor

Instituto Pirenaico de Ecología, CSIC

Zaragoza

humberto@ipe.csic.es 
Highlights (for review)

- Recent land uses contribute to soil erosion in marginal lands

- Long history of human activity explains many landscape characteristics

- Intensification and extensification/wealth and poverty increase spatial complexity 


\title{
Erosion in Mediterranean landscapes: Changes and future challenges
}

José M. García-Ruiz a *, Estela Nadal-Romero b, Noemí Lana-Renault c, Santiago Beguería d

a Instituto Pirenaico de Ecología, CSIC, Campus de Aula Dei, Apartado 13.034, 50080-

Zaragoza, Spain. humberto@ipe.csic.es

b Department of Geography and Land Management, University of Zaragoza, 50009Zaragoza, Spain.

c Area of Physical Geography, University of La Rioja, 26004-Logroño, Spain.

d Estación Experimental de Aula Dei, CSIC, Campus de Aula Dei, Apartado 13.034, 50080-Zaragoza, Spain.

* Corresponding author. Tel.: +34 976369393 (ext. 880047), fax: +34 974363222

\begin{abstract}
Intense erosion processes are widespread in the Mediterranean region, and include sheet wash erosion, rilling, gullying, shallow landsliding, and the development of large and active badlands in both subhumid and semi-arid areas. This review analyses the main environmental and human features related to soil erosion processes, and the main factors that explain the extreme variability of factors influencing soil erosion, particularly recent land use changes. The importance of erosion in the Mediterranean is related to the long history of human activity in a region characterized by low levels of annual precipitation, the occurrence of intense rainstorms and long-lasting droughts, high evapotranspiration, the presence of steep slopes and the occurrence of recent tectonic activity, together with the recurrent use of fire, overgrazing and farming. These factors have resulted in a complex landscape in which intensification and abandonment, wealth and poverty can co-exist. The changing conditions of national and international markets and the evolution of population pressure are now the main drivers explaining land use changes, including farmland abandonment in mountain areas, the expansion of some subsidized crops to marginal lands, and the development of new terraces affected by landslides and intense soil erosion during extreme rainstorm events. The occurrence of human-related forest fires affecting thousands of hectares each year is an increasing problem in both the northern and southern areas of the Mediterranean basin. Here, we highlight the rise of new scientific challenges in controlling the negative consequences of soil erosion in the Mediterranean region: (i) to reduce the effects and extent of forest
\end{abstract}


fires, and restructure the spatial organization of abandoned landscapes; (ii) to provide guidance for making EU agricultural policy more adapted to the complexity and fragility of Mediterranean environments; (iii) to develop field methods and models to improve the identification of runoff and sediment contributing areas; (iv) to contribute to the conservation of landscapes (i.e. bench-terraced fields) having high cultural and productivity values; (v) to improve knowledge of the hydrological and geomorphological functioning of badlands, with the aim of reducing sediment yield and accessibility; (vi) to better understand the effect of climate change on soil erosion in the Mediterranean region; and (vii) to improve quantitative information on long-term soil erosion.

Key words: Erosion, Badlands, Land use changes, Intensification, Land abandonment, Mediterranean landscapes

\section{Introduction}

Since at least the second half of the 19th century, erosion has been recognized as one of the most significant environmental problems worldwide (Bakker et al., 2007), particularly in areas having seasonally contrasted climate and a long history of human pressure. This is the case for the Mediterranean region, where concerns about soil loss and its consequences emerged as natural forests disappeared because of the expansion of livestock rearing, recurrent fires and the cultivation of steep slopes (LópezBdermúdez, 2008). The landscape in many Mediterranean areas, especially in southeast Spain, Greece and northern Africa, suggests that the interaction between climate, topography, soil characteristics and human activity has led to short- and mid-term unsustainability. In addition, the development of a highly specialized flora and the emergence of a large number of endemic species make a return to natural conditions difficult following perturbation (Alados et al., 2011).

A recent review of European sediment yields demonstrated that Mediterranean rivers have higher yields than those in the rest of Europe, which has been attributed to climate, topography, lithology and land use (Vanmaercke et al., 2011). The presence of active badlands, gullies and eroded torrential headwaters, bedrock-exposed hillslopes, soil surfaces having abundant pebbles and cobbles, thin soils, rill and inter-rill erosion in cultivated fields, shallow landsliding, evidence of soil redistribution, overloaded streams and aggrading sedimentary structures are amongst the geomorphic problems 
that receive most attention from geomorphologists, agronomists and forest engineers. Nevertheless, in the Mediterranean region these problems occur in close proximity to areas that are very well preserved, with dense shrub or forest cover, complex soil conservation structures and the absence of water-erosion. The co-existence in the Mediterranean region of areas of extremely high ecosystem productivity with areas showing dramatic soil erosion and degradation processes is directly or indirectly related to the ways in which human societies in the region have organized land management throughout history.

The study of soil erosion in the Mediterranean region is also the study of geomorphic extremes. The occurrence of extremely intense and high volume rainstorms, and the consequent floods, have few parallels in other areas of the temperate zone, and the erosion rates recorded in some badland areas are well beyond those in other parts of Europe. There are rarely intermediate conditions: many of the rivers are almost dry for most of the year, but periodically are subject to catastrophic floods that change the channel morphology, destroy bridges, and cause heavy loss in terms of human lives, houses and infrastructure (Poesen and Hooke, 1997; Belmonte and Beltrán, 2001; Wittenberg et al., 2007; Ortega and Garzón Heydt, 2009; Machado et al., 2011). Each landscape is a palimpsest, with features inherited from the activities of past cultures and remnants of geomorphic processes that partially determine the management of the land and its subsequent geomorphic processes. For this reason, complexity is another key Mediterranean characteristic. Thornes (2002) noted that one of the major difficulties in understanding and studying the Mediterranean region is that it has one of the world's most complicated landscapes, because of local variations in topography, soils and surface water conditions, which result in extremely rapid changes in soil depth, infiltration capacity, gradient, and plant cover characteristics. Very productive irrigated fields having flat or undulating relief contrast over distances as little as hundreds of meters or several kilometers with areas having steep slopes affected by various water erosion processes and shallow landslides, with a variety of plant communities. The presence of areas markedly disturbed by fires contrasts with areas where there has been expansion of natural vegetation following farmland abandonment (Hill et al., 2008). The simple difference between a shadowed to sunny aspect on a small hill can be reflected in a dramatic change from a geomorphic and hydrological perspective. Wealth and poverty are near. These factors explain the long-term and increasing interest of geomorphologists worldwide in studying soil erosion in the Mediterranean region: the 
enormous spatial and temporal variability, and the challenge of unravelling the various parts of the palimpsest. Understanding of many Mediterranean geomorphic processes has been aided by several seminal publications, particularly those of Brandt and Thornes (1996), Conacher and Sala (1998a), Mairota et al. (1998), Geeson et al. (2002) and Wainwright and Thornes (2004).

Here we provide a review of soil erosion problems in the Mediterranean region, and the knowledge gaps and challenges for the immediate future. The main objective was to provide a global perspective on the factors that explain the spatial diversity of erosion processes and the complexity of erosion landscapes, as a basis for identifying the most important gaps in information. We identified the main research areas studied and analysed the distribution of such studies throughout the Mediterranean, and the methods used. We then focused on: (i) the particular geomorphic-like characteristics that make the landscape so complex, and the occurrence of processes at various spatial scales; (ii) the key characteristics of soil erosion in the Mediterranean region (i.e. the contrast between intensification and abandonment); and (iii) the challenges for the future in addressing erosion in the Mediterranean region. The review is centred on countries adjacent to the Mediterranean Sea, and not on Mediterranean-type areas in California, central Chile, southern Australia and the Cape region of South Africa, although most of the problems discussed are common to these regions.

\section{Erosion in the Mediterranean region: an overview of the literature}

Soil erosion is one of the most intensively studied subjects in the Mediterranean region. A total of 670 papers in this area were identified using the ISI and Scopus databases. The information obtained enabled classification of the papers according to topic, country and methods. Within the Mediterranean region, the importance of soil erosion studies in Spain has been stressed by García-Ruiz (1999): soil erosion and hydromorphological studies, represented $16.8 \%$ of the total number of papers, and constituted a larger proportion than studies of more classical topics, including coastal geomorphology, glacial geomorphology, Quaternary deposits, karst, fluvial geomorphology, regional geomorphology, paleoforms and structural geomorphology. The number of soil erosion and hydromorphological studies peaked during the 1990s, when they represented $22.7 \%$ of the total, suggesting recent recognition of soil erosion as a crucial environmental problem. Soil erosion studies have constituted a very substantial part of the recent evolution of geomorphology in other Mediterranean 
countries, although to a lesser extent than in Spain. Fig. 1 shows the distribution of soil erosion studies by country. Most of the studies published in SCI journals relate to Spain (380), followed by Italy (88), France (52 of relevance to Mediterranean France), Portugal (28), Israel (19), and Greece (17 papers). Together, the countries in North Africa account for 40 papers.

Fig. 2 shows that for the entire Mediterranean region, studies of badlands dominated (233), followed by studies on soil erosion related to agriculture (soil erosion in various crops or under different tillage techniques: 119 papers). The other research areas are also relevant for geomorphologists, although they remain far from the first two topics: the relationships between vegetation and erosion, including deforestation and afforestation (100 papers), erosion after forest fires (74), soil erosion modelling (50), the role of extreme events (47), the consequences of farmland abandonment (42), reservoir silting (27), and the connectivity between hillslopes and channels (12). The evolution of the major topics is represented in Fig. 3, which shows a remarkable increase since 1990. The first increase occurred in studies of badlands, which accounted for the greatest number of studies each year. Papers on the effects of agriculture increased after 1995, with a new pulse evident after 2003, and studies on the consequences of farmland abandonment increased after 2005. Positive temporal trends are also evident for the remaining topics, although these have not been as consistent as for the studies of badlands and agriculture.

The study topics dominating among the countries differed (Fig. 4), suggesting variations in relative importance among the diversity of erosion problems. For instance, badlands have been the main focus of geomorphologists in Spain, followed by forest fires and, to a lesser extent, agricultural erosion, farmland abandonment, vegetationerosion relationships, and extreme events. In Italy, badlands have been almost the only area of interest, while in France badlands have been the most studied topic, followed by agricultural erosion. However, in Portugal and Israel badlands have rarely been studied, with fires being the subject of most of studies. In North Africa, studies of agricultural erosion have emphasized the concern of scientists for soil conservation under conditions of increasing demographic pressure. Thus, studies of badlands have dominated in Spain, Italy and France; forest fires have been the major concern in Portugal (and also of importance in Spain, Italy and Israel). Erosion resulting from farming has been the main focus in North Africa (and also of importance in Spain and France); and farmland abandonment is a relatively important problem almost exclusively in Spain. 
With respect to the methods used in studying soil erosion in the Mediterranean region (Fig. 5), modelling has dominated and increased in importance in recent years, followed by the use of experimental plots, rainfall simulations, and the interaction between field work and laboratory analyses. There have also been a number of papers dealing with experimental catchments, remote sensing and GIS. Studies using other methods, including erosion pins, bathymetry, isotopes and dendro-geomorphology, have constituted a smaller proportion.

\section{What makes erosion in the Mediterranean region so unique?}

The Mediterranean region is unique from a planetary perspective, occupying a small area surrounding the Mediterranean Sea, and giving its name to a type of temperate climate that dominates generally narrow fringes close to coastlines. There is general agreement that the Mediterranean climate transitions rapidly towards oceanic, continental and subdesert climates in northern Spain-southern France, the Balkans and the Near East-North Africa, respectively. The Mediterranean Sea has a significant influence on the environmental characteristics of the Mediterranean region, but not enough to explain the peculiarities of the Mediterranean climate. In fact, Mediterraneantype climates occur in other regions of the world including California, Central Chile, South Africa and southern Australia. It represents a transition between cold-humid and warm-dry climates, between $\sim 25$ and 40 degrees latitude in the west coast of the continental landmasses (Olivier, 2005). The map shown in Fig. 6 illustrates the area of influence of the Mediterranean climate in southern Europe, the Near East and North Africa. The Iberian Peninsula is the largest territory, although it has marked continental characteristics towards the interior.

Analyses of precipitation and temperature confirm that the Mediterranean climate is unique worldwide. It is the only climate in which summer is both dry (frequently, extremely dry) and very hot. Fig. 7 shows the mean monthly temperature and precipitation measured at weather stations in the Mediterranean region: Lisbon, Valencia, Naples, Athens, Algiers and Tel-Aviv. For each of these stations a similar pattern is evident, with low moderate temperatures in winter and high temperatures in summer (generally peaking in August), whereas precipitation is concentrated during the cold period (particularly from October to May), in contrast with the very dry summer. The mean annual precipitation usually ranges from 400-600 $\mathrm{mm}$, whereas the mean annual temperature is $\sim 16-19^{\circ} \mathrm{C}$. Nevertheless, there are differences within the 
Mediterranean. Thus, the mean annual precipitation can exceed 600 (and even $800 \mathrm{~mm}$ ) in the hilly areas of the northern Mediterranean (e.g. close to the eastern Pyrenees and in the foothills of the Sierra Nevada in Spain, and in the Po Valley and the Apennines in Italy), and the mean temperature is $<15^{\circ} \mathrm{C}$ in the interior of the Iberian Peninsula, $\left(\sim 0^{\circ} \mathrm{C}\right.$ in January and February, with some days of freezing temperatures between November and March/April). The precipitation regime also shows regional variation: In the western Mediterranean, two small peaks of precipitation occur, in autumn and spring, and a short dry period occurs in winter (January, February) in the western Mediterranean, whereas winter is the wettest period in the rest of the study area. June to September is a period of very low mean precipitation, although June can be relatively wet in the northern sector, with occasional rainstorms (Gil-Olcina, 2007). In the mountains, some of the features of the Mediterranean climate still persist (particularly the precipitation regime, with the typical seasonal contrast), but a variable proportion of the precipitation falls as snow, and temperatures are markedly lower. For this reason, the highest Mediterranean mountains (the central and eastern Pyrenees, Iberian Range, Central Range and Penibetics in Spain; the Apennines, Corsica and Sardinia in Italy; the southern Alps in Provence, France; the Pindo Mountains in Greece; the Rif and Tell mountains in Morocco and Algeria; and the Lebanon Mountains) have been defined as sub-Mediterranean.

The low values for mean annual precipitation mask interannual variability, which is a similarly important characteristic of the region, whereby humid years alternate with very dry years that have $<250 \mathrm{~mm}$ precipitation. This feature is critical for the development of vegetation, particularly when periods of dry years occur in cycles (Vicente-Serrano and Cuadrat-Prats, 2007). However, extremely intense rainstorms can occur, with precipitation of $>200 \mathrm{~mm}$ occurring in only a few hours (Llasat and Puigcerver, 1992; López-Bermúdez and Romero-Díaz, 1993). Such events sometimes trigger large floods (Poesen and Hooke, 1997; Wainwright and Thornes, 2004; Gaume et al., 2009) that change channel morphology and affect bridges, roads and human lives, and have major geomorphological effects (Thornes, 1976; White and García-Ruiz, 1998; González-Hidalgo et al., 2007; Nadal-Romero et al., 2012a; Serrano-Muela et al., 2013). Gaume et al. (2009) noted that, in the context of Europe, the most extreme flash floods occur in the Mediterranean region. Extreme floods in the Mediterranean can exceed the mean discharge by more than a factor of 100, and change the discharge from zero to several hundred cu meters (Belmonte and Beltrán, 2001). 
Scarcity and abundance characterize the Mediterranean, in this case because high temperatures in the Mediterranean Sea at the end of summer coincide with the arrival of cold air masses at high altitude (cutoff low systems), resulting in very active thermodynamically unstable depressions (Nieto et al., 2005). These reach their greatest intensity in the coastal areas of the Mediterranean, and are intensified by the steep mountains that are common near the coast. Their effects tend to be reduced rapidly towards the interior, especially in the Iberian Peninsula.

The interaction between relief and climate is of particular importance. Although old, Hercynian mountains are present including in some sectors of the central and eastern Pyrenees, the Sierra Nevada, the Iberian Range, and the Atlas Mountains, most of the relief derives directly from Alpine tectonics, and has highly variable lithology. This gives the Mediterranean landscape a peculiar roughness and energy, with steep slopes and marked differences in height between the divides and the valley bottoms or the coast. Even where the divides correspond to old erosion levels, the incision of the fluvial network always gives the impression of rugged mountains. Some mountains were raised in the latter stages of Alpine tectonics, only several millions years ago, and are still seismically active. This is particularly the case for the Penibetic range in Spain, the Apennines, and mountains of Greece and Turkey, where seismic activity has induced landsliding and enhanced short- and long-term erosion processes through raising of the relief and consequent incision by rivers (Maher and Harvey, 2008).

As noted above, the presence of rugged mountains close to the coastline enhances the activity of Mediterranean lows pressure systems in autumn, and the energy of floods flowing in very steep rivers and through ravines. The relief roughness and the markedly varying insolation results in dramatic contrasts between north and south facing slopes over very short distances (tens to hundreds of metres), and cause extreme differences in soil humidity, evaporation rates, plant cover density and structure, and soil erosion. This contributes to very distinct environments (steppe, dense shrub cover and forest), occurring in close proximity.

The climatic characteristics of the Mediterranean region directly condition the composition and structure of plant cover. Prior to the presence of permanent settlements, most of the region was covered by dense forests of pines (Pinus halepensis, P. nigra, P. peuce, P. leucodermis), evergreen oaks (Quercus ilex), cork trees (Q. suber) and cedars (Cedrus atlantica), accompanied by a diverse undergrowth well adapted to droughts and to the strong seasonality in soil humidity. These forests are adapted to the dry summer 
period having deep root networks, and ceasing vegetative growth during summer. Other types of oaks and pines, as well as deciduous trees, dominated the Mediterranean mountains. In the driest areas (central Ebro Depression, south-east Spain and the edges of the sub-desert) the forests were open or replaced by steppes. The complexity of the relief and the contrasts between north and south facing slopes resulted in a mosaic of vegetation having an exceptional species richness, amongst which many are endemic to the Mediterranean region.

Thousands of years of human activity have strikingly transformed the vegetation and landscape characteristics of the Mediterranean region. One of the most influential features has been the long history of varying cultures and peoples. The Mediterranean region is the origin of some of the most interesting and advanced cultures, which have had a relatively strong capacity to disturb the landscape and extract benefit from the natural resources. The expansion of agriculture and animal domestication from the Fertile Crescent and Mesopotamia explains the early deforestation of some areas, the use of fire as an instrument to control shrubs and forests, and the presence of sheep and goat flocks. The development of permanent settlements was a critical threshold for the triggering of soil erosion processes, leading to early records of many landscapes showing signs of severe degradation more than 2000 years ago (Conacher and Conacher, 1998). The history of the Mediterranean peoples has been convoluted, with alternating periods of war, stability, expansion and abandonment, resulting in changes in plant cover, sediment yield, fluvial morphology, and valley bottoms and coastal sedimentation. It is noteworthy that land management in the Mediterranean is typically very complex. Societies depend on the stability of the system: the welfare of many people is based on olive and almond orchards, or vineyards, which are labour-intensive plants that are not immediately productive. Similarly, for irrigated lands the ditches and water-distribution networks need to be maintained permanently, and for bench terraced fields regular maintenance is required to repair landslides at the terrace borders. The occurrence of wars or social conflicts has frequently resulted in the collapse of land management systems and initiation of erosion processes, particularly where farmers have used marginal areas for food production, even for a short term. It is typically very expensive to undertake construction and land works in the Mediterranean landscape, and even short-term crises can necessitate very expensive reconstruction. A simple factor such as population growth can cause instability, necessitating increased crop production at the expense of soil conservation works. Similarly, farmland abandonment 
following a period of population emigration can result in the destruction of many conservation structures, which become very difficult to repair decades or centuries later, if population pressure returns.

The susceptibility of Mediterranean soils to erosion under changing conditions is exacerbated by deforestation, frequent fires and the cultivation of steep slopes. Generally, Mediterranean soils are considered as the "most fragile part" of the system (Salvati and Bajocco, 2011) because of several factors: (i) The low soil organic matter ( $\mathrm{SOM}$ ) content (frequently $\leq 2 \%$ ) is a consequence of high summer temperatures, which stimulate rapid mineralization of fallen leaves; in many places fires and the dominance of open shrubs in many sites also contribute to low SOM contents. This factor explains poor soil structure and the susceptibility of the soil to raindrop impact (Cammeraat and Imeson, 1998). (ii) The rate of formation of soils is usually slow, and the profiles are thin and poorly developed (Conacher and Conacher, 1998). Poesen and Hooke (1997) pointed out that Mediterranean soils have a low soil loss tolerance level (T-factor), that is much lower than in soils under temperate humid climatic conditions. Many authors consider that rate of soil formation in the Mediterranean area (probably $<1 \mathrm{tha}^{-1} \mathrm{yr}^{-1} ; \mathrm{A}$. Cerdà, pers. comm.) is less than the soil erosion rates where plant cover is disturbed. Erosion rates measured in many Mediterranean environments suggest an imbalance between soil formation and erosion (Poesen and Hooke, 1997). (iii) The removal of vegetation by grazing and livestock trampling hinders plant recovery and soil reconstruction, and results in the development of an impervious structural crust on the soil surface, which reduces water infiltration capacity and decreases the production of organic matter. Nevertheless, it is noteworthy that thin soils developed on metamorphic rocks are subject to very low annual erosion rates $\left(<2 \mathrm{t} \mathrm{ha}^{-1} \mathrm{yr}^{-1}\right)$ (Sougnez et al., 2011), confirming the controlling role of rock substratum.

Several studies have investigated the hydrogeomorphological role of rock fragments in soil. The abundant presence of pebbles and cobbles is an established characteristic of Mediterranean soils, and the proportion of these has increased because of erosion of fine particles. Poesen and Ingelmo-Sánchez (1992) and Poesen and Lavee (1994) confirmed that rock fragments tend to favour infiltration, reducing runoff and soil loss. This is an important observation, indicating that soil erosion is regulated with progressive reduction of sediment output as the proportion of rock fragments increases (Ruiz-Flaño et al., 1992). 


\section{Soil erosion and landscape transformation: short-term and long-term changes}

Soil erosion is a relatively slow phenomenon, although in some cases the effects of erosion are highly visible, as in the case of some extreme events in the Mediterranean region (rainstorms and floods corresponding to long return periods). Several extreme events have been studied, including analysis of the characteristics of rainstorms, their spatial distribution, and the consequences for hillslope and fluvial morphology (Benito et al., 2008). The main consequences of floods include changes in sedimentary structures of the fluvial channels, incision of first and second order channels, widening of the alluvial plain, accumulation of blocks and boulders, talus erosion, destruction of riparian vegetation, and landslides resulting from the undermining of stream banks, as described by Martí-Bono and Puigdefábregas (1983) and Clotet et al. (1989) in the central-eastern Pyrenees (events in November 1982), Ortega and Garzón Heydt (2009) in central-western Spain, and Le Lay and Saulnier (2007) in Cevennes-Viverais, southeast France. Landslides resulting from the undermining of stream banks are the main and most immediate sediment sources during floods because of the arrival of large amounts of heterogeneous materials, although the hillslopes can yield enormous volumes of fine material and clasts resulting from the activation of gullies and the development of ephemeral rills and shallow landslides that evolve into debris flows (Bathurst et al., 2007). The occurrence of extreme rainstorms often results in the erosion of the most fertile soil horizons from cultivated fields. Thus, De Alba et al. (1998) estimated the soil loss from cultivated fields during a rainstorm event of $70 \mathrm{~mm}$ in 45 minutes in August 1995 at Rielves, central Spain, to $\geq 351 \mathrm{t} \mathrm{ha}^{-1}$, which is a factor of 48 more than the annual erosion rate from 1993-1997 in experimental plots in the same area.

The steep longitudinal gradients of streams, even in their lower courses, markedly increases the destructive effects of floods, including the occurrence of avulsions that change stream routes (e.g. Cariozza et al., 2012). Steep slopes in the basin, and typically low infiltration rates in many cases (because of thin soils and the low density of plant cover) explain the high concentration times of floods, which advance rapidly through the channel with high destructive capacity. Nevertheless, the area affected by the most extreme rainstorm events is sufficiently localized that large floods occur infrequently. The consequent absence of hydrological memory among the population leads to the construction of roads, streets, stalls, parking areas and houses in the fluvial channel, increasing the catastrophic effects of some flood events (Mateu- 
Bellés, 1988). The last two kilometres of the Arás ravine (Central Spanish Pyrenees) has a longitudinal gradient of $20 \%$, and following a flood with an estimated flow of $300 \mathrm{~m}^{3}$ $\mathrm{s}^{-1}$ on August 1996, 40 check-dams were destroyed, the stream was enlarged by several metres and a campsite in the alluvial fan was devastated resulting in 89 casualties. The exceptional magnitude of this event is evident when it is considered that the flood occurred in a basin of only $18 \mathrm{~km}^{2}$ (White et al., 1997).

Most changes in Mediterranean landscapes can only be detected over the long term. Assessments of hillslopes and channels have confirmed that erosion has resulted in new morphologies at various altitudinal belts. The occurrence of stony soils and gullies with sparse vegetation is not the consequence of a few extreme rainstorms, but the slowly developed effect of overland flow, sheet wash erosion and rilling. Many landscapes in Crete, Cyprus, Turkey, Lebanon, Israel, northern Algeria, the Rif Mountains in Morocco, and certain places in south-eastern France and central and southern Spain have similar features, including the presence of shrubs interspersed with open spaces in which soil is almost absent or the bedrock is at the surface. These are landscapes with a long history of cultivation, recurrent use of fire, and grazing. In many cases, rapid deforestation has been responsible for sudden increases in erosion rates, as demonstrated in a study of sediment accumulated in lakes (Montserrat, 1972). A consequence of deforestation in the landscape was the development of active torrential headwaters, deeply incised parallel gullies, shallow landslides and a general redistribution of the soil. In the long-term, such geomorphological changes result in the development of infilled valley bottoms, braided rivers, alluvial fans and deltas. Geoarchaeological and geomorphological studies have demonstrated the intensity and rapidity of erosion and accumulation processes in historical times throughout the Mediterranean basin, and the important role of human societies in these processes (Bruckner, 1986; Van Andel et al., 1986).

Infilled valley bottoms are a very important part of Mediterranean landscapes in lowland hilly areas where intense soil erosion processes have occurred in the past. These valleys are identified by their flat topography, the low gradient in their longitudinal profile, and the typical presence of a fine sediment infill of $\leq 20 \mathrm{~m}$ depth. The infill usually forms an abrupt lateral connection with the hillslopes, which are usually almost bare of vegetation, with a thin soil layer or no soil. Analysis of such sediments revealed the presence of pottery and other archaeological remains, which indicates that infilling (and erosion on the hillslopes) occurred in relatively recent times, 
and suggests the interaction of Holocene climate fluctuations with human activity. Peña et al. (1995, 2000; Gutiérrez-Elorza and Peña-Monné, 1998; Harvey and GutiérrezElorza, 2005; Casana, 2008; Constante et al., 2010). However, some authors have suggested the importance of the geomorphological effects of the Little Ice Age (Vita Finzi, 1969; Grove, 2001). In a study at Bardenas, Spain, Sancho et al. (2008) investigated Holocene deposits on Miocene clays surrounded by structural platforms, and identified four sedimentary units.

The development of alluvial fans is closely related to stages of erosion processes, many of which correspond to Quaternary environmental changes. Other erosion processes have been related to land use changes and deforestation in historical times. Gómez-Villar et al. (2006) concluded that the presence or absence of alluvial fans in basins of the Iberian Range, northern Spain, could be interpreted as a consequence of human activity. Fans are always present in catchments affected by deforestation and farming in the past.

This is similar to progradation of the coastal plain at many sites around the Mediterranean. Thus, Grove and Rackham (2001) found that the mouth of the Andarax River (south-east Spain) was an estuary 2500 years ago. Deforestation and mining activity from the middle of the 18th century was the likely cause of the formation of a 6 $\mathrm{km}^{2}$ delta. Also in southern Spain, the estuary of the Vélez River was infilled during the Upper Holocene as a consequence of deforestation linked to extractive metallurgy, resulting in the development of a delta that has penetrated into the Mediterranean Sea at a rate of 0.2-2 m per year since the 16th century (Lario et al. 1995). This has increased with the expansion of vineyards and cereal crops on steep slopes. Malvárez et al. (1998) and Ruiz and Carmona (2005) reported that this has been a common feature of the evolution of many Mediterranean rivers. In some cases, this evolution in historical times was spectacular, as occurred for the Ebro and Po river deltas since Roman times. Although it is very difficult to establish cause and effect relationships in large basins (thousands of $\mathrm{km}^{2}$ ) because of the presence of many sediment stores, it seems that the Ebro Delta has advanced towards the Mediterranean Sea as deforestation progressed. The period of maximum deltaic progradation occurred between the 15th and 19th centuries, coinciding with a general expansion of sheep flocks and cereal cropping in the Ebro basin, and continuous growth in population that resulted in increased cultivation of marginal slopes. The concentration of certain industrial activities in the Mediterranean mountain areas during the 18th and 19th centuries was associated with a 
marked concentration of human population (Gómez-Urdáñez, 1986). This probably explains the large expansion of cereal crops in steep slopes with the construction of bench-terraced fields and the expansion of shifting agriculture. Nevertheless, this period coincided with the Little Ice Age, which would have enhanced the activity of floods and geomorphic processes.

\section{Land-use intensification and extensification}

The Mediterranean region is a place of marked environmental and socioeconomic contrasts at various spatial scales. Perhaps the most surprising characteristic from a land management perspective is the presence of areas subjected to extreme landuse intensification adjacent to areas in which extensification and abandonment of productive activities are the most common features. Where similar processes have occurred in many places worldwide, the intensity of the changes elsewhere is not comparable with that of the northern area of the Mediterranean. This is a consequence of the concentration of population, industry, wealth, initiative and investment in mainly coastal areas and some cities in the interior (Wainwright and Thornes, 2004; RicoAmorós et al., 2009). In contrast, most areas of the Mediterranean region underwent a process of economic and demographic stabilization or declined, with the abandonment or extensification of farmland activities, ageing of the population, and the absence of development initiatives. Both trends had crucial hydrological and geomorphological consequences, although with different implications.

Land-use intensification in the Mediterranean region came with the introduction of more intensive cropping systems, particularly the enlargement and modernization of irrigated lands, and the growth of urban and industrial areas that resulted in enlargement of sealed impervious surfaces.

Generally, irrigation does not produce any erosion problems in the short-term, because of the smooth gradient of irrigated fields. For this reason, irrigated lands can remain productive for centuries, providing that incorporation of organic matter continues and water distribution is controlled. Nevertheless, under certain circumstances problems have become evident. Irrigated soils having a high sodium content tend to be affected by piping erosion because of the hydrological gradient caused by the presence of small steps $(<2 \mathrm{~m})$ between fields, particularly in plots cultivated over several years with alfalfa (García-Ruiz et al., 1997). Water wastage in some irrigated lands led to modernization, with changes towards more productive and also higher water-consuming 
crops, plot concentration to enlarge the size of plots, and general use of sprinkling irrigation. Plot concentration eliminates the steps between plots, resulting in local increases in gradient and the development of rills and small gullies. However, the major problems arise from the expansion of irrigated agriculture into marginal areas, where the soils rapidly lost structure and become intensively eroded and later abandoned. In south-east Spain, for example, some of the affected areas evolved into badlands (Cerdà, 1997; Romero-Díaz et al., 2007). Cerdà et al. (2012) observed that agricultural intensification (expansion of citrus orchards) at the expense of abandoned fields leads to accelerated soil erosion, exceeding by several orders of magnitude the erosion recorded for abandoned fields and rainfed cultivated fields.

Urban growth and the consequent expansion of industrial areas have also resulted in hydrological and geomorphological changes. In particular, coastal areas of Spain, Italy and southern France have been subject to the growth of cities and villages, and the development of urbanization related to tourism, in a process the intensity of which has few rivals worldwide. In north-east Spain, Sala and Inbar (1992) confirmed the occurrence of more frequent and larger floods because of the enlargement of impervious areas since the 1960s. Flash floods in the City of Genova, Italy, have been attributed to urban development on the hillslopes rising from the coast behind the City (Conacher and Sala, 1998b). Gabert and Nicod (1982) noted that some of the most dramatic floods in the vicinity of Marseille and Aix-en-Provence, France, were exacerbated by the construction of many buildings and roads on flood plains. Clearly, more floods result in more erosion, and in some cases incision and widening of rivers and ravines.

For some decades many Mediterranean landscapes have been subject to a progressive reduction in human activity, including farmland abandonment and decreasing livestock pressure. The reasons for this extensification include declining populations (with losses of $\sim 80 \%$ of the inhabitants from some rural areas since the beginning of the 20th century), the inability to use mechanized agriculture on many cultivated hillslopes, and the ageing of the population and the consequent lack of manpower to maintain sheep flocks and the traditional transhumance system. The result has been abandonment of farming in hilly and mountainous areas, and the progressive recolonization by shrubs and forests. This has had dramatic hydrological and geomorphological effects, particularly in the Mediterranean region, where the greatest farmland abandonment has been relatively recent (García-Ruiz and Lana-Renault, 2011). 
These authors concluded that plant recolonization has resulted in a decline in water resources and decreased soil loss and sediment delivery, as well as a progressive improvement in soil characteristics. Until 60-70 years ago a large proportion of the Mediterranean mountains and semi-arid areas were cultivated with cereal crops, even on steep slopes, stony soils and under extremely dry conditions. At present, most fields in the mountains have been abandoned, with the exception of some areas in Andalusia, Sicily, Calabria, Greece and North Africa. The replacement of cereal fields and intervening fallow periods by shrubs and forests has produced changes in rainfall infiltration, the spatial organization of saturation-prone areas, runoff generation processes (Mohammad and Adam, 2010; Nadal-Romero et al., 2012b), rainfall partitioning, evapotranspiration, the location of sediment sources, and the accessibility of sediment to the fluvial network. Declining stream flows have been one of the major consequences (Cosandey, 1990; Gallart and Llorens, 2004; Cosandey et al., 2005; Morán-Tejeda et al., 2010; García-Ruiz et al., 2011; Lana-Renault et al., 2011).

Beguería et al. (2003) analysed data from gauging stations located upstream of reservoirs in the Spanish Pyrenees, and confirmed a change in the relationship between precipitation and discharge; the latter has been declining since the beginning of the 1970s, and has coincided with generalized abandonment of farmland. In a Europeanwide study, Stahl et al. (2010) concluded that there has been a negative trend in stream flow in Mediterranean rivers over the period 1962-2004. Significant increases in SOM content, aggregate stability, hydraulic conductivity and water holding capacity have been observed throughout the Mediterranean region, including Spain (Trimble, 1990; Martínez-Fernández et al., 1995; Ruecker et al., 1998; Pardini and Gispert, 2006, 2012) and Greece (Kosmas et al., 2000). At the scales considered, soil erosion generally declined after abandonment, as well as the connectivity between sediment sources and channels, with reduced sediment delivery (Hooke, 2006; Lana-Renault and Regüés, 2009; García-Ruiz et al., 2010; Quiñonero-Rubio et al., 2013) and sedimentation in reservoirs (Navas et al., 2011). An exception was some areas of pine reforestation on bulldozed terraces in marly semi-arid areas of south-east Spain, where soil loss increased by 1-2 orders of magnitude (Romero-Díaz et al., 2010).

Changes in sediment yield have also had consequences for Mediterranean rivers (Hooke, 2006). Bed degradation and the development of bed armouring and channel narrowing have been detected in several tributaries in the Rhône basin (Liébault and Piégay, 2001, 2002), and in Pyrenean rivers (Beguería et al., 2006), whereas some 
Italian rivers underwent a change from braiding toward single-thread channels (Surian et al., 2010; Comiti et al., 2011), with extensive streambed degradation threatening the stability of infrastructure, as has occurred in the Arno River (Billi and Rinaldi, 1997). In the Dragonja River floodplain, south-west Slovenia, Keesstra et al. (2005) found an incision of $1.5 \mathrm{~m}$ between 1945-1975, following farmland abandonment and natural reforestation after 1945. Inactivation of alluvial fans in the areas most affected by farmland abandonment was detected in the Sila Massif, southern Italy (Garfi et al., 2007), and in the Pyrenees, where large alluvial fans showed reductions in the area occupied by active areas and incision in historical sediments (Gómez-Villar and GarcíaRuiz, 2000). The construction of many check-dams in torrential rivers and ravines has contributed to a reduction in sediment yield (Boix-Fayos et al., 2007), although a part of the fluvial energy then erodes downstream of the dams (Boix-Fayos et al., 2008). Mediterranean deltas have also been destabilized by the construction of large reservoirs, which behave as sediment traps, reducing sediment transfer towards the sea (Tena et al., 2011).

Farmland abandonment also occurred in semi-arid areas of south-east Spain, because of the extremely low productivity of rainfed fields. However, plant colonization has been difficult: the low volumes of annual precipitation and its irregular seasonal distribution, including intense rainfall events occurring over very short time periods, reduce the capacity of vegetation to recolonize the fields in a few years. In addition, the soils are low in nutrients and SOM, constraining plant succession. This has limited the capacity of old fields to produce organic matter and increase water infiltration, which tends to be restricted because of the development of soil surface crusts (Ries and Langer, 2001). Lesschen et al. (2007) reported an increase in gully erosion in the Cárcavo basin (south-east Spain), following land abandonment, because of greater runoff caused by soil crusting. Farmland abandonment is still an incipient process in North Africa, where population pressure is leading to cultivation of all available areas, including steep slopes (Maurer, 1992; Lahlou, 1996), and to degradation of rangelands by overgrazing (Puigdefábregas and Mendizábal, 1998).

The evolution of abandoned bench-terraced fields has become one of the major soil conservation problems in the Mediterranean region. Terraced fields are very common close to the Mediterranean coast and in mountain areas in Spain, Italy, Greece, Lebanon, Israel and North Africa. The construction of terraced fields has a history of many centuries, although some terraces in Mediterranean mountain areas were probably 
constructed during the periods of greatest population pressure in Mediterranean mountain areas (18th and 19th centuries). They were originally one of the measures used to preserve soil and facilitate agricultural practises based on animal labour. The transformation of hillslopes to a series of flats and steps represented an enormous investment of manpower devoted to avoiding the development of gullies, controlling overland flow and improving infiltration, under conditions of intense rainstorms, steep slopes and low levels of mean annual precipitation. Bench-terraced fields made soil conservation possible and provided for relatively high crop productivity. However, the stone walls needed to be repaired each year by the local populations, which explains why magnificent landscapes are still possible on steep slopes after centuries of cultivation. Nevertheless, such landscapes are now unsustainable, because mechanized agriculture is not possible in most bench-terraced fields, and there is a generalized lack of manpower. The consequence has been the abandonment of most bench-terraced fields, except in North Africa, Caldea in Israel, the low versants of the Anti-Lebanon mountains, and some hillslopes of the Alpujarras and Sierra Nevada in Andalusia, Spain. In some Mediterranean countries the maintenance of terraces can be only justified by their use for highly profitable or subsidized crops, such as olive trees, vineyards and irrigated citrus.

The abandonment of bench-terraced fields leads to the development of small mass movements in the steps, resulting in scars that can evolve into short gullies that are impossible to repair in the present circumstances (Lasanta et al., 2001; Kizos and Koulouri, 2006; Koulouri and Giourga, 2007). Lesschen et al. (2008) compared the 1984 and current versions of a Digital Elevation Model (DEM) to estimate soil losses from bench terraces of south-east Spain, and concluded that average erosion rates are $\sim 87 \mathrm{Mg} \mathrm{ha}^{-1} \mathrm{yr}^{-1}$, which is comparable to rates reported in some semi-arid badlands. Erosion problems have been exacerbated where re-organization of the drainage system following abandonment has resulted in the incision of new channels and reestablishment of the natural drainage network and connectivity (Gallart et al., 1994; Oostwoud Wijdenes et al., 1999; Bellin et al., 2009; Gallart, 2009; Meerkerk et al., 2009). However, Llorens et al. (1997) and Cammeraat et al. (2005) reported that plant colonization was rapid and sufficiently dense to reduce landsliding in the Alcoy basin, south-east Spain, and in the eastern Pyrenees. Some studies of the hydrological effects of terrace abandonment have reported the development of saturated areas in the inner 
parts of terraces during the wet season, thus favouring overland storm flow (Gallart et al., 1994; Seeger and Ries, 2008).

\section{The erosion consequences of changing agriculture}

The Mediterranean region is fully integrated into a market economy where subsidies are common. This explains the rapid adaptation of farmers to changes in price and demand. Even farmers of northern Algeria, Tunisia and Morocco are adapted to these changes, substituting crops or investing in the expansion of irrigated lands (Badraoui et al., 1998). Agricultural adjustments are closely related to the advantages of the Mediterranean climate, which enables cultivation of a large variety of crops from cold temperate to sub-tropical climates. This provides many economic and technical opportunities for farmers, although soil erosion can be an unexpected problem, particularly where marginal lands are taken into cultivation, including fields that were abandoned some decades ago.

It is not easy to reconcile cultivation and soil conservation in Mediterranean environments. The occurrence of extreme rainstorm events reduces the effectiveness of any conservation measure, and can result in short-term soil losses equal to the total losses over many years. Nevertheless, some crops are more prone to soil erosion than others. There is a paucity of quantitative information on soil erosion under various crops in the Mediterranean, but the available data confirm that cereal cultivation can be affected by rilling and gullying, even on smooth gradients (Casalí et al., 1999; Kosmas et al., 2002), with increasing soil loss as mean precipitation increases (Kosmas et al., 1997; Jebari et al., 2010). In cereal cultivation the soil is bare during autumn and part of winter, which coincides with one of the rainiest periods in the Mediterranean region and the season having the most intense rainstorms, particularly in the western Mediterranean. The introduction of no-tillage crop systems appears to offer the only possibility of reducing soil erosion without a decrease in production.

Other typical Mediterranean crops are at risk of similar or greater erosion problems. Kosmas et al. (1997), De Santisteban et al. (2006), Ramos and MartínezCasasnovas (2006a), Casalí et al. (2009), Cerdan et al., (2010) and Novara et al. (2011) reported that vineyards are subject to the highest erosion rates, which is of major importance given that the area occupied by vineyards in 2010 was $1,172,797$ ha in Spain, 377,991 ha in south France (Langedoc-Roussillon, Provence and Rhône), 777,480 ha in Italy, 99,286 ha in Greece, and 73,000 ha in Algeria. Two of the most 
important erosion problems in vineyards are: (i) the low level of plant cover $(5-40 \%)$ from November to April, particularly in the case of young vineyards, where plant cover is almost completely absent for most of the year; and (ii) the steepness of vineyard slopes. Thus, in La Rioja, northern Spain, almost 20\% of vineyards are cultivated on hillslopes having a gradient $>10 \%$ (Ruiz-Flaño et al., 2006). This makes vineyards particularly susceptible to heavy rainfall and soil erosion. Farmers attempt to combat soil erosion with the use of herbicides in summer and limiting ploughing during the remainder of the year (Blavet et al., 2009), although to overcome soil erosion more efforts must be made to incorporate reduced tillage systems. Nevertheless, slope steepness can be partially compensated for by the presence of many stones on the soil surface (sometimes representing almost $100 \%$ of soil cover), which increases infiltration and the soil moisture content (Arnáez et al., 2007). Even so, it is relatively common to find rills on convex hillslopes following rainstorms in autumn or spring, and sediment patches at the lower end of plots. Ruiz-Flaño et al. (2006) found that $40.8 \%$ of vineyards are affected by sedimentation, $17.5 \%$ by sheet wash erosion, and $5.2 \%$ by rilling, whereas $35.6 \%$ were unaffected by degradative geomorphic processes.

Ramos and Martínez-Casasnovas (2006b) analysed a recent interesting case of enhanced soil erosion in a vineyard in the Penedès region, north-east Spain, which also has implications for other areas in the Mediterranean region. The old bench-terraced fields, which were separated by steps with stone walls, were recently transformed into large terraces to enable the use of mechanization and the introduction of drip irrigation. The resulting mixing of the fertile topsoil with the subsoil represented an impoverishment of the soil, and a decrease in the stability of the steps against landslides, because of their greater height. The infiltration capacity also decreased because of soil sealing, mainly during the most intense rainstorms. This is an example of modern landscape transformation done with the purpose of increasing incomes, but the intensification resulted in increased soil erosion problems, exacerbating the vulnerability of vineyards to intense rainstorms.

Similar problems have occurred in rainfed almond and olive orchards (GarcíaRuiz, 2010). Almond and olives are typical Mediterranean crops that are well adapted to sparse and irregular precipitation, and both (particularly almond trees) are commonly cultivated on hillslopes and marginal lands. Olive groves occupy large areas in Spain, Italy, Greece, and to a lesser extent, North Africa. In some regions olive groves represent a large proportion of the cultivated area (e.g. Andalusia, Spain), and have 
become virtually the only crop on many farms and municipalities. For many centuries olive groves have been cultivated on bench-terraced fields to avoid soil erosion (above all in Mallorca Island, inner Catalonia, Aragón, Sicily and Greece), forming stable landscapes that have survived until the present. Nevertheless, erosion problems have been accentuated by changes in land management and the availability of subsidies from the EU. Thus, De Graaf and Eppink (1999) and Kosmas et al. (1997) concluded that the practise of clean weeding under olive trees and the replacement of manure by fertilizers has reduced infiltration capacity, enhancing runoff and rilling. Bienes et al. (2012) stated that the most efficient land management factor controlling erosion in olive orchards is the permanent presence of grasses. Subsidies have promoted the extension of olive groves into marginal areas (Van Wesemael et al., 2006), rather than favouring production quality, including environmental and soil conservation aspects. The situation is similar for almond orchards, with the further difficulty that almond trees have traditionally been cultivated on stony pediments that are not always bench-terraced. Faulkner (1995) noted that large areas colonized by Mediterranean shrubs have been replaced in the last two decades with almond trees, generally on steep slopes; this is a trend that contrasts with the efforts of some countries to control soil erosion.

\section{Badlands and forest fires: the face of the Mediterranean?}

Two topics that have attracted particular attention from geomorphologists and, to a lesser extent, ecologists, are badlands and forest fires, which are amongst the most representative and important problems in the Mediterranean. Badlands areas have the highest erosion rates in the world (Bryan and Yair, 1988), and generally have a high level of connectivity with the fluvial network. This affects the suspended sediment load and the development of sedimentary structures in rivers (López-Tarazón et al., 2009), and causes serious siltation in reservoirs (Nadal-Romero, 2011). Fires pose a serious short-term risk of soil erosion, but can also result in land degradation and sometimes desertification over the long-term. The presence of badlands and fires in the landscape makes them the most impressive features in many Mediterranean areas. Not surprisingly, in recent decades badlands and fires have been most extensively studied in Spain, Portugal, Italy and Israel (Fig. 4), and are the first and fourth subjects of interest to geomorphologists throughout Europe (Fig. 2).

Badlands occur in a wide range of Mediterranean environments, from humid and sub-humid (mean precipitation $\sim 800 \mathrm{~mm}$ per year) to semi-arid $\left(<350 \mathrm{~mm} \mathrm{yr}^{-1}\right)$ areas 
(Gallart et al., 2013). These develop in dramatic patches (from a few hectares to hundreds or thousands of hectares) characterized by the almost total absence of vegetation and a dense network of ephemeral ravines incising soft, erodible rocks. Bedrock of lutite and marl are the most prone to the dynamic evolution of badlands, although they can also occur on shale (Nadal-Romero et al., 2011, 2012d). Lutite and marl are extremely common among the Neogene sediments that folded during the Alpine tectonics or were deposited in post-tectonic times, as is the case of the lowlands in the Apennines, Italy; the Betic Ranges and the Ebro Depression in southern and northern Spain, respectively; and the Rif Mountains in northern Morocco. The presence of these impervious rocks and the development of a highly impermeable regolith are two factors explaining the development of badlands in the Mediterranean region, together with a long history of human burning and cropping of steep slopes. This makes plant recolonization very difficult after soil removal (Gallart et al., 2002) in a double scenario: (i) rainfalls that erodes the regolith in the sub-humid badlands, and (ii) intense dryness in the semi-arid badlands.

A consequence is that few plants, if any, can tolerate the extreme conditions of the badland soil surface, and consequently badlands can remain and enlarge for hundreds or thousands of years, with little prospect of change in the short-term. However, the development of small patches of herbs and shrubs is possible, providing that they grow on soil remnants and accumulation areas having relatively low gradients. Studies based on geoarchaeological and sedimentological evidence have reported that some badlands pre-date human settlement and the development of agriculture and cattle raising (Wise et al., 1982). In other cases, badland development seems to be unequivocally related to farming and recurrent fires, particularly those that occur in small areas close to villages and cultivated lands (García-Ruiz and López-Bermúdez, 2009).

Most studies of Mediterranean badlands have focused on infiltration capacity, spatial and seasonal variability of runoff and sediment yield, weathering factors, erosion processes, piping, crust development, the protective role of lichens, interactions between vegetation and erosion, and runoff and sediment response during rainfall events. It is noteworthy that in the subhumid and humid badlands, which are generally located in areas having cold winters, the number of frost days is a major factor explaining regolith weathering, particularly on shaded landscapes, whereas the main factor on sun-exposed aspects is the temporal contrast in regolith humidity (Nadal- 
Romero et al., 2007). The latter is also a determining factor in the evolution of semiarid badlands. In both cases there is a disconnect among regolith weathering, erosion and sediment export. Weathering tends to mainly occur in winter, which is the period having most frequent freezing days and the deepest penetration of humidity. Erosion and sediment outputs mainly occur in spring, when part of the weathered regolith is washed from the slopes or affected by mudflows, and carried out to the channels where it accumulates because of the extremely high sediment load. The channels are cleared by summer and autumn rainstorms, at least in the humid and sub-humid badlands, where the period of badland activity is longer than in the semi-arid badlands.

Badland areas produce the highest rates of sediment production in the Mediterranean, particularly in humid and sub-humid environments, because of the deep and intense weathering processes affecting the bedrock and the relatively high annual precipitation. Sediment yields of hundreds of tonnes per square kilometre and per year have been estimated (Mathys et al., 2005; Nadal-Romero et al., 2008a; Regüés et al., 2009; López-Tarazón et al., 2012), although the area considered plays a major role in determining the yield (Nadal-Romero et al., 2011, 2012d). In semi-arid and arid regions, the dramatic badland landscapes also suggest the occurrence of high erosion rates, although the low mean precipitation results in relatively low sediment yield (Cantón et al., 2001; Gallart et al., 2002) For the arid badlands (i.e. in Near East including Turkey, Syria, Lebanon, Israel and Jordan), the low level of erosion processes has led to the conclusion that they may have been more humid areas in the past (Yair et al., 1980).

The other visible face of the Mediterranean is the occurrence of large forest fires, which have immediate impacts on the future evolution of plant cover, because of their significant effects on soil characteristics, runoff generation and soil erosion (Gimeno et al., 2000; Wittenberg and Inbar, 2009; Shakesby, 2011). Fires resulting from both natural and human-induced causes are a common feature of the Mediterranean region, and explain some of the main adaptative features of the Mediterranean vegetation, particularly its capacity for regeneration through survival of roots and bulbs. Lacustrine, fluvial and colluvial sediments contain charcoal and ashes from thousands of years ago, demonstrating the occurrence of natural forest fires throughout the Mediterranean (Colombaroli et al., 2009; Gil-Romera et al., 2010; Rius et al., 2011; Vannière et al., 2011; Lasheras-Álvarez et al., 2013). Natural forest fires would have been caused by lightning during 'dry rainstorms', which probably occurred relatively infrequently. The frequency of such fires increased after Neolithic times and particularly from the Bronze 
Age, as demonstrated by Rius et al. (2011) in the central French Pyrenees, and by Vannière et al. (2011) for the entire Mediterranean region. Following the Bronze Age, fire frequency was driven by agro-pastoral activities and was used as an agent of landscape management. For instance, the analysis of sediments from Tramacastilla Lake in the central Spanish Pyrenees demonstrated the occurrence of fires of limited extent $\sim 3500$ yr BP, which were followed by relatively rapid forest recovery. A new period of forest fires occurred $\sim 1000 \mathrm{yr} \mathrm{BP}$, when the subalpine forests were burnt to enlarge the area occupied by grasslands to provide feed for livestock in summer (Montserrat, 1972). The geomorphological consequences of these historical fires are well documented in the sedimentary records, through dramatic increases (several orders of magnitude) in sedimentation rates.

In traditional farming, fire was used to prepare the land for cultivation under shifting agriculture, or to remove the remnants of previous crops (i.e. the cereal stubble). Shepherds frequently used fire to remove thorny shrubs, which improved the quality of grasslands (Enne et al., 2002). This mainly occurred immediately prior to spring, favouring the growth of herbs and tender sprouts of shrubs. Margaris and Koutsidou (2002) reported that fire could be beneficial if used every 10-20 years along with controlled grazing, but problems occur if fire is used almost annually, probably because of subsequent soil compaction, and increasing soil erosion and overland flow as a consequence of livestock trampling, which progressively reduces soil quality and the potential for rapid plant regeneration. In most Mediterranean countries the use of fire was forbidden some decades ago.

The recent occurrence of forest fires has no historical precedent, as evidenced by the number of fires and their extent in some Mediterranean countries. Thus, during 2009, the areas burnt included 87,416 ha in Portugal, 100,783 ha in Spain, 73,355 ha in Italy, 35,443 ha in Greece and 134,720 ha in Morocco. For this reason, forest fires have become a major research area from geomorphological, hydrological, pedological and ecological perspectives, with the most frequently studied associated phenomena being changes in infiltration capacity, soil structure, hydrophobicity, plant colonization, overland flow, sediment yield and the effects of fire intensity (temperature of the soil surface and subsurface).

The reasons for the recent increase in fire impacts are well known, and are related to land management changes in rural environments, particularly in Spain, southern France, Italy and Greece. The marked decrease in the rural population explains 
the declining pressure on natural resources, related to a reduction in the number of livestock, which in the past reduced the abundance of shrubs. The prohibition on the use of controlled fires to manage grasslands has also enhanced the expansion of shrubs. Finally, farmland abandonment has resulted in a complex process of plant recolonization that has led to the expansion of dense shrubs and forests (García-Ruiz and Lana-Renault, 2011). Artificial reforestation was a policy for the restoration of degraded areas, and to limit soil erosion and reservoir siltation. The consequence has been that many Mediterranean areas evolved into simplified and continuous landscapes with plenty of flammable wood (Úbeda et al., 2005). The absence of cultivated fields and meadows, which can act as barriers to fire spread, has enhanced the occurrence of fires affecting thousands of hectares. Negligent visitors to areas recolonized with natural vegetation can trigger large wildfires, although the origin of many fires is the burning of cereal stubble in fields located close to shrub or forest areas in the middle and at the end of summer, coinciding with the period of maximum risk at the peak of the driest season. Speculative purposes are not discarded in some cases, although they were probably more important in the past. Thus, during recent decades, forest fires in the Mediterranean region have changed significantly, with serious impacts on soil erosion: traditionally, fires were of limited extent and commonly occurred in spring, whereas present-day fires can affect thousands of hectares, mainly in summer.

The occurrence of fires has immediate consequences for soil erosion (e.g. Shakesby and Doerr, 2006). The temporary removal of plant cover leaves the soil unprotected, which enhances overland flow and soil erosion because of a decrease in infiltration capacity (evidence of frequent hydrophobicity: Bodí et al., 2012) and the direct impact of raindrops. Generally, ash is easily removed by overland flow and wind, both of which limit the recycling of nutrients and contribute to water and air pollution. However, it is noteworthy that in most cases plant recovery is rapid, with regrowth of shrub and herbaceous cover again protecting the soil within several months (Cerdà, 1998; Cerdà and Lasanta, 2005; Gimeno-García et al., 2007; Wittenberg and Inbar, 2007). Ruiz-Flaño et al. (1992) have argued that the recurrence of forest fires, even to the limited extent that occurred under traditional management systems, periodically enhances soil erosion and progressively reduces the potential for plant recolonization, leading to open shrub communities on stony soils. This explains the many degraded Mediterranean landscapes in Spain, Italy, Greece and North Africa. 


\section{Challenges for the future}

Land use changes and diverse forms of intensification and extensification reveal the consequences of recent land management changes in the Mediterranean region. These changes have been the consequence of new circumstances in the Mediterranean landscape, with lower population numbers in rural areas and the need to rapidly increase incomes to finance expenditure on farm improvements, and the purchase of new fields and machinery. This has changed the relationship between the farmer (who can be transformed into a manager with little connection to the land) and the landscape. The new situation solves many erosion problems, as the replacement of cereal crops by shrubs and forests in abandoned fields changes the relationships between precipitation and hydrological responses (Beguería et al., 2003), and reduces sediment yield, although other problems can become evident. New efforts must be made to combat soil erosion and desertification with a holistic approach, particularly to reduce the size of sediment sources and their accessibility to fluvial channels. Nevertheless, predictions for the future indicate a major threat of erosion-induced productivity decline in southern Europe (Bakker et al., 2007).

As a consequence of changes resulting from land management decisions, geomorphologists now face new challenges and questions that have not yet been adequately addressed (Boardman, 2006). It is time to define what we know and what we need to know to enable greater efficiency and to avoid past mistakes. It is important to know more about the traditional and current land uses to clarify how land use change has influenced the hydrological behaviour of hillslopes and channels. Knowledge of the spatial variability of soils, topography and climate will provide information on the fluxes of water and sediment through hillslopes and will aid forecasting of the reaction of the ecosystem to changes in plant cover, crops and conservation measures. Therefore, the first challenge is to be more holistic; that is, to perceive soil erosion as a complex system in which human activity and agricultural practises are the main drivers. The main challenges, discussed in more detail below, for soil erosion scientists in the Mediterranean region are: (i) to reduce the effects and extent of forest fires in a scenario of increasing expansion of shrub and forest areas; (ii) to provide guidance for adapting EU agricultural policy to the complexity and fragility of Mediterranean environments; (iii) to develop field methods and models to improve the identification of runoff and, particularly, sediment contributing areas; (iv) to contribute to the conservation of landscapes with high cultural and productive values; (v) to improve knowledge of the 
hydrological and geomorphological functioning of badlands, with the aim of reducing sediment yield and accessibility; (vi) to better understand the influence of climate change on soil erosion in the Mediterranean; and (vii) to improve long-term quantitative information on soil erosion.

(i) Forest fires. The evolution of forest fires in the Mediterranean region indicates that the problem is far from solved. The most important factor is the simplification of the landscape whereby thousands of hectares of continuous, easily flammable shrubs and forests now occur throughout Spain, Portugal, Italy and Greece, and to a lesser extent in the other Mediterranean countries. Plant colonization following farmland abandonment has reduced peak flows, stream flow, and suspended sediment and bed loads. Nevertheless, a wildfire can rapidly negate these positive effects, exponentially increasing sediment yield and delivery for several months. The only solution is to increase diversity, in particular by clearing abandoned fields located in the most adequate topographic conditions, generally those on concave hillslopes with deep soils and sufficient humidity to allow the development of grazing meadows (Lasanta et al., 2009). The construction of complex land use mosaics with a variety of patches does not avoid the occurrence of fires, but would reduce their extent. Geomorphologists have to work jointly with specialists in landscape ecology and human geography to define a conceptual and quantitative framework within which this task could be integrated.

(ii) EU agricultural policy. One of the most important environmental problems is that the EU agricultural policy places more importance on the extent of cultivated land rather than on crop yields. Thus, subsidies depend on the number of hectares cultivated rather than on the yield produced. A consequence is that many farmers enlarge their cultivated area, including shrub removal, to include marginal and steeper lands with thin soils, rather than improving water and soil conservation measures. Subsidies must require integration of productivity and soil conservation; geomorphologists can contribute to this by providing knowledge on the erosion effects of various land uses in the Mediterranean region. Models and experimental plots and catchments can help to establish the environmental limits for subsidized crops.

(iii) Field methods and models. It is well known that sediment exported from a catchment comes from a small part of the territory, even if the catchment is affected by intense erosion processes. Thus, a task for geomorphologists is to develop methods to identify runoff and sediment source areas ("hot spots", according to RECONDES, 2007), the location of water and sediment sinks, and accessibility to fluvial channels. 
The following step is to understand how to reduce the connectivity between the most eroded areas and channels, and how to promote new water and sediment sinks (Kirkby et al., 2002; Latron et al., 2009). The purpose of this is to reduce sediment outputs, and to take targeted action on selected hillslopes to progressively reduce the area of sediment sources. A reduction in reservoir silting should be a major objective to extend the useful life-span of reservoirs, given their financial, environmental and socioeconomic importance. It is important to take into account that soil erosion control measures must also influence runoff generation and accessibility to the fluvial network. Failure to do this will result in an imbalance in the relationships between water and sediment, causing new problems in the fluvial bed. An issue that hydrogeomorphologists should address is whether changes can be made to hillslopes to maintain the balance between water and sediment at the catchment scale. This requires that catchments (and the relationships between hillslopes and channels) must be considered as systems in which any change affects the other elements of the system. This approach will help scientists and technicians avoid making major but flawed changes and investments and facilitate assessment of the key steps taken towards increasing the efficiency of restoration programes (Cortina et al., 2011).

(iv) Conservation of landscapes. Farmers in historical times contributed to the construction of magnificent landscapes based on their investment of enormous amounts of energy. These landscapes are also the result of extensive empirical knowledge about water and sediment fluxes. However, the conservation of these landscapes depends on the continuous supply of energy. This was the case for bench-terraces, which covered large areas mostly in the Mediterranean hills and mountains. These conserved huge quantities of soil carried from neighbouring hillslopes or from the alluvial plains. When such landscapes became unsustainable because of the declining and aging rural population and their impractically for modern agricultural practices, they were abandoned and the system collapsed. This resulted in the development of landslides at the borders of terrace steps, and occasionally in gully development. The maintenance of these outdated landscapes is a major task for the immediate future, because their degradation will lead to an increase in sediment yield and to the degradation of a cultural legacy that could be productive for diverse purposes: to feed livestock; to produce, where appropriate, selected labour-intensive consumer crops; or to become sites of high tourism value. 
(v) Hydrological and geomorphological functioning. Understanding of the hydrological and geomorphological dynamics of badlands has improved markedly in recent decades. Badlands are the landform most studied by geomorphologists in the Mediterranean region and they are also the most important sediment sources. More information is needed on these areas with respect to the seasonality of sediment yield, connectivity with the fluvial network, the relationships among runoff, erosion and lichen colonization (Calvo-Cases et al., 1991; Lázaro et al., 2008), and the hydromorphological functioning of badland borders. Such studies will aid understanding of the evolution of badland ecotones (Alatorre and Beguería, 2009; Nadal-Romero et al., 2012c). Large Mediterranean badland landscapes (including the Bardenas, Monegros and Tabernas Desert, in Spain; the Crete Senesi of southern Tuscany and Basilicata in Italy; Draix in France; and the Zin Valley in Israel) are impressive and must be preserved as special geomorphological sites and as laboratories for the study of geomorphic processes. Probably there is nothing that can be done to prevent the transport of sediment from these large badlands to the main rivers, because of the high sediment yield and the typical occurrence of flash floods, although future studies can help to: (a) detect changes in badland areas related to climate and land use changes (Nadal-Romero et al., 2012c); (b) identify the factors and their seasonality that contribute most to weathering of the bedrock; (c) improve understanding of the relationships between hillslopes and channels, including the capacity of channels to store sediment and to reduce the arrival of sediment from hillslopes; (d) identify the relationships among weathering, erosion and sediment export in relation to varying rainstorm events; (e) relate the geomorphic dynamics of badlands to the evolution of other geomorphic landforms, including piedmonts, and to fluctuations in the incision and sedimentation processes in ravines coming from badlands; and (f) explore the interactions between vegetation and erosion processes under varying climatic conditions (Maccherini et a1., 2011).

(vi) Climate change. The relationships between climate change and erosion are unclear, given the uncertainties about the future trajectories of temperature and precipitation. Nevertheless, this is a key issue for land degradation and soil erosion (Calvo-Cases and Harvey, 1996; De Luís et al., 2010). Factors that need to be studied in view of their influence on the location of sediment source areas, splash effects, sediment delivery to the fluvial network, and behaviour of sediment sinks include: the future evolution of plant cover; possible changes in soil characteristics (infiltration capacity, 
organic matter content, structure); water storage within soils (which is clearly related to precipitation and evapotranspiration); the intensity and seasonality of heavy rainfall events; and the redistribution of runoff generation areas.

(vii) Long-term quantitative information. One of the most frustrating aspects of the study of soil erosion is the impression that published erosion rates are subject to remarkable uncertainty. Erosion and sedimentation processes are scale-dependent (de Vente and Poesen, 2005; de Vente et al., 2007), such that soil erosion rates measured at one scale can be very different from those measured at a different scale. For this reason a variety of erosion rates are reported for the different land cover/land uses (Fig. 8), including those obtained from rainfall simulations, experimental plots and catchments. Furthermore, the figures for sediment yield at the scale of small catchments can vary enormously, depending on the accessibility of detached particles to channels, the location of landslides in relation to the fluvial network, and the presence of topographic irregularities that can behave as temporary sediment stores. In addition, it is very difficult to know whether the period covered by any particular dataset included extreme events. The usually short study time period for most geomorphological experiments reduces the value of the data obtained. For this reason we did not include erosion rates in this study. For the future, an agreement between scientists is necessary to standardize methods and establish the temporal and spatial scales over which erosion rates can be compared and their usefulness for assessing soil conservation measures.

\section{Conclusions}

The main purpose of this study was to provide a global perspective on the factors that explain the spatial diversity of erosion processes and the complexity of erosion-prone landscapes in the Mediterranean region. Intense erosion processes are widespread in the area, particularly sheet wash erosion, rilling, gullying, shallow landsliding and the development of active badlands in subhumid and semi-arid areas. These processes are the consequence of complex interactions between environmental and human-related factors. The complex mosaic that characterizes the Mediterranean landscape is a product of the occurrence of intense rainstorms and prolonged droughts, the presence of steep slopes, topographic diversity, high evapotranspiration, recent tectonic activity, and the long history of human activity reflected in the recurrent use of fire, overgrazing and farming. Such complexity explains why some areas are well preserved, including those with dense plant cover and deep soils, whereas in other areas 
most of the soil and plant cover has been lost, and they are now degraded, covered by stones and affected by rilling and gullying. Wealth and poverty, and land management intensification and extensification co-exist, resulting in a variety of hydrological and geomorphological processes. Thus, widespread land abandonment has occurred in all Mediterranean countries, particularly on the northern side of the basin. Affected areas are large and characterized by shrub recolonization and reforestation, which reduces runoff and sediment source areas, and thereby sediment yield and stream flow. Nevertheless, plant recolonization over large areas has resulted in the occurrence of extensive wildfires that can affect hundreds of thousands of hectares each year and can have important erosion consequences. Other areas are affected by increasing erosion because of land use intensification arising from expansion of cultivation areas in response to population growth (North Africa), poorly targeted subsidies (vineyards, almond and olive orchards), attempts to increase profits through irrigation, and the expansion of urban areas into rural zones.

Many Mediterranean landscapes can be considered to be 'man-made' or human and for this reason need the presence of a rural population if they are to be preserved. This is the case for bench-terraced fields, which have a history of construction over several centuries; these enabled cultivation on slopes and avoided soil erosion. Their recent evolution has been dominated by landslides between the terraces and by gullying, processes that have led to the degradation of these impressive cultural relics. In other cases, population migration and EU Agrarian Policy have encouraged land use changes that have not been considered in the context of their impact on infiltration rates, water storage and the connectivity between hillslopes and channels. Many areas of the Mediterranean appear to be degraded, while others have maintained their geoecological functions. Efforts must be invested in understanding the hydromorphological functioning of the former, even if they are poorly productive,. Both types of area need to be considered as part of a delicate equilibrium between nature and the long history of human occupation. In addressing erosion problems in the region, in most cases largescale ill-considered responses (large scale reforestations, use of expensive structures) must be avoided.

\section{Acknowledgements}

Support for this research was provided by the projects INDICA (CGL201127753-C02-01 and -02), HIDROCAES (CGL2011-27574-C02-01) and DISDROSPEC 
(CGL2011-24815), funded by the Spanish Ministry of Economy and Competitiveness and the European Regional Development Fund (ERDF-FEDER), ACQWA (FP7-ENV2007-1-212250), financed by the European Commission, and an agreement between the CSIC and the Spanish Ministry of Environment (RESEL). The Geomorphology and Global Change research group was financed by the Aragón Government and the European Social Fund (ESF-FSE). E. Nadal-Romero and N. Lana-Renault benefited from a research contract (Spanish Ministry of Economy and Competitiveness, Programme Juan de la Cierva). The authors acknowledge the comments from Prof. Mike Fullen and an anonymous referee, as well as the editorial labour from Prof. Takashi Oguchi.

\section{References}

Alados, C.L., Puigdefábregas, J., Martínez-Fernández, J. 2011. Ecological and socioeconomical thresholds of land and plant-community degradation in semi-arid Mediterranean areas of sotheastern Spain. Journal of Arid Environments 75, 13681376

Alatorre, L.C., Beguería, s. 2009. Identification of eroded areas using remote sensing in a badlands landscape on marls in the central Spanish Pyrenees. Catena 76, 182-190.

Arnáez, J., Lasanta, T., Ruiz-Flaño, P., Ortigosa, L. 2007. Factors affecting runoff and erosion under simulated rainfall in Mediterranean vineyards. Soil \& Tillage Research 93, 324-334.

Bakker, M.M., Govers, G., Jones, R.A., Rounsevell, M.D.A. 2007. The effect of soil erosion on Europe's crop yields. Ecosystems 10, 1209-1219.

Bathurst, J.C., Moretti, G., El-Hames, A., Beguería, S., García-Ruiz, J.M. 2007. Modelling the impact of forest loss on shallow landslide sediment yield, Ijuez catchment, Spanish Pyrenees. Hydrology and Earth System Sciences 11, 569-583.

Badraoui, M., Soudi, B., Fahrat, A. 1998.Variation de la qualité des sols: une base pour évaluer la durabilité de la mise en valeur agricole sous irrigation par pivot au Maroc. Étude et Gestion des Sols 5(4), 227-234.

Beguería, S., López-Moreno, J.I., Llorente, A., Seeger, M., García-Ruiz, J.M. 2003. Assessing the effect of climate oscillations and land-use changes on streamflow in the Central Spanish Pyrenees. Ambio 32 (4), 283-286. 
Beguería, S., López-Moreno, J.I., Gómez-Villar, A., Rubio, V., Lana-Renault, N., García-Ruiz, J.M. 2006. Fluvial adjustments to soil erosion and plant cover changes in the Central Spanish Pyrenees. Geografiska Annaler 88A (3), 177-186.

Bellin, N., Van Wesemael, B., Meerkerk, A., Vanacker, V., Barberá, G.G. 2009. Abandonment of soil and water conservation structures in Mediterranean ecosystems. A case study from southeast Spain. Catena 76, 114-121.

Benito, G., Thondycraft, V.R., Rico, M., Sánchez-Moya, Y., Sopena, A. 2008. Paleoflood and floodplain records from Spain: Evidence for long-term climate variability and environmental changes. Geomorphology 101, 68-77.

Bienes, R., Marqués, M.J., Ruiz-Colmenero, M. 2012. Cultivos herbáceos, viñedos y Olivares. El manejo tradicional del suelo y sus consecuencias en la erosion hídrica. Cuadernos de Investigación Geográfica 38 (1), 49-74.

Billi, P., Rinaldi, M. 1997. Human impact on sediment yield and channel dynamics in the Arno River (central Italy). IAHS Publ. 245, 301-311.

Blavet, D., De Noni, G., Le Bissonnais, Y. Leonard, M., Maillo, L., Laurent, J.Y., Asseline, J., Leprun, J.C., Arshad, M.A., Roose, E. 2009. Effect of land use and management on the early stages of soil water erosion in French Mediterranean vineyards. Soil \& Tillage Research 106, 124-134.

Boardman, J. 2006. Soil erosion science: Reflections on the limitations of current approaches. Catena 68, 73-86.

Bodí, M.B., Cerdà, A., Mataix-Solera, J., Doerr, S.H. 2012. Repelencia al agua en suelos forestales afectados por incendios y en suelos agrícolas bajo distintos manejos y abandono. Cuadernos de Investigación Geográfica 38 (2), 53-74.

Boix-Fayos, C., Barberá, G.G., López-Bermúdez, F., Castillo, V.M. 2007. Effects of check dams, reforestation and land-use changes on river channel morphology: case study of the Rogativa catchment (Murcia, Spain). Geomorphology 91, 103-123.

Boix-Fayos, C., de Vente, J., Martínez-Mena, M., Barberá, G.G., Castillo, V 2008. The impact of land use change and check-dams on catchment sediment yield. Hydrological Processes 22, 4922-4935.

Brandt, C.J., Thornes, J.B. (eds.) 1996. Mediterranean desertification and land use. John Wiley, Chichester.

Bruckner, H. 1986. Man's impact on the evolution of the physical environment in the Mediterranean region in historical times. GeoJournal 13 (1), 7-17. 
Bryan, R.B., Yair, A., eds. 1988. Badland geomorphology and piping. GeoBooks, Norwich, $408 \mathrm{pp}$.

Calvo-Cases, A., Harvey, A.M. 1996. Morphology and development of selected badlands in southeast Spain: implications of climatic change. Earth Surface Processes and Landforms 21, 725-735.

Calvo-Cases, A., Harvey, A.M., Payá-Serrano, J., Alexander, R.W. 1991. Response of badland surfaces in south east Spain to simulated rainfall. Cuaternario y Geomorfología 5, 3-14.

Camarasa Belmonte, A.M., Segura Beltrán, F. 2001. Flood events in Mediterranean ephemeral streams (ramblas) in Valencia region, Spain. Catena 45, 229-249.

Cammeraat, L.H., Imeson, A.C. 1998. Deriving indicators of soil degradation from soil aggregation studies in southeastern Spain and southern France. Geomorphology 23, 307-321.

Cammeraat, E., Van Beek, R., Kooijman, A. 2005. Vegetation succession and its consequences for slope stability in SE Spain. Plant and Soil 278, 135-147.

Cantón, Y., Domingo, F., Solé-Benet, A., Puigdefábregas, J. 2001. Hydrological and erosion response of a badlands system in semiarid SE Spain. Journal of Hydrology $252,65-84$.

Carozza, J.M., Puig, C., Odiot, T., Valett, P., Passarrius, O. 2012. Lower Mediterranean plain accelerated evolution during the Little Ice Age: Geoarchaeological insight in the Tech basin (Roussillon, Gulf of Lion, Western Mediterranean). Quaternary International 266, 94-104.

Casalí, J., López, J.J., Giráldez, J.V. 1999. Ephemeral gully erosion in southern Navarra (Spain). Catena 36, 65-84.

Casalí, J., Giménez, R., De Santisteban, L., Álvarez-Mozos, J., Mena, J., Del Valle Lersundi, J. 2009. Determination of long-term erosion rates in vineyards of Navarre (Spain) using botanical benchmarks. Catena 78, 12-19.

Casana, J. 2008. Mediterranean valleys revisited: Linking soil erosion, land use and climate variability in the Northern Levant. Geomorphology 101, 429-442.

Cerdà, A. 1997. Soil erosion after land abandonment in a semiarid environment of South eastern Spain. Arid Soil Research and Rehabilitation 11, 163-176.

Cerdà, A. 1998. Post-fire dynamics of erosional processes under Mediterranean climatic conditions. Zeitschrift für Geomorphologie 42, 373-398. 
Cerdà, A., Lasanta, T. 2005. Long-term erosional responses after fire in the Central Spanish Pyrenees: 1. Water and sediment yield. Catena 60, 59-80.

Cerdà, A., Giménez Morenra, A., Burguet, M., Arcenegui, V., González Peñaloza, F.A., García-Orenes, F., Pereira, P. 2012. El impacto del cultivo, el abandono y la intensificación de la agricultura en la pérdida de suelo. El ejemplo de la vertiente norte de la Serra Grossa en el Este peninsular. Cuadernos de Investigación Geográfica 38 (1), 75-94.

Cerdan, O., Govers, G., Le Bissonais, Y., Van Oost, K., Poesen, J., Saby, N., Gobin, A., Vacca, A., Quinton, J., Auerswald, K., Klik, A., Kwaad, F.J.P.M., Raclot, D., Ionita, I., Rejman, J., Rousseva, S., Muxart, N., Roxo, M.J., Dostal, T. 2010. Rates and spatial variations of soil erosion in Europe: A study based on erosion plot data. Geomorphology 122, 167-177.

Clotet, N., García-Ruiz, J.M., Gallart, F. 1989. High magnitude geomorphic work in Pyrenees range: November's 1982 unusual rainfall event. Studia Geomorphologica Carpatho-Balcanica 23, 69-91.

Colombaroli, D., Tinner, W., Van Leeuwen, J., Noti, R., Vescovi, E., Vanniere, B., Magny, M., Schmidt, R., Bugmann, H. 2009. Response of broadleaved evergreen Mediterranean forest vegetation to fire disturbance during the Holocene: insights from the peri-Adriatic region. Journal of Biogeography 36, 314-326.

Comiti, F., Da Canal, M., Surian, N., Mao, L., Picco, L., Lenzi, M.A. 2011. Channel adjustments and vegetation cover dynamics in a large gravel bed river over the last 200 years. Geomorphology 125, 147-159.

Conacher, A., Conacher, J. 1998. Introduction. In: A.J. Conacher and M. Sala, (Eds.), Land degradation in Mediterranean environments of the world. Nature and extent, causes and solutions, Wiley, Chichester, pp. XIII-XXVI.

Conacher, A.J., Sala, M. (eds.) 1998a. Land degradation in Mediterranean environments of the world. Nature and extent, causes and solutions. John Wiley, Chichester, 491 pp.

Conacher, A. Sala, M. (1998b). The causes of land degradation. 2: Vegetation clearing and agricultural practices. In: A.J. Conacher and M. Sala (Eds.), Land degradation in Mediterranean environments of the world. Nature and extent, causes and solutions, Wiley, Chichester, pp. 285-307. 
Constante, A., Peña, J.L., Muñoz, A., Picazo, J. 2010. Climate and anthropogenic factors affecting alluvial fan development during the late Holocene in the central Ebro Valley, northeast Spain. The Holocene 21, 275-286.

Cortina, J., Amat, B., Castillo, V., Fuentes, D., Maestre, F.T., Padilla, F.M., Rojo, L. 2011. The restoration of vegetation cover in the semi-arid Iberian southeast. Journal of Arid Environments 75, 1377-1384.

Cosandey, C. 1990. Étude des crues Cévenoles: conditions d'apparition dans un petit basin versant forestier sur le varsant sud du Mont Lozère. IAHS Publ. 191, 103-115.

Cosandey, C., Andréassian, V., Martin, C., Didon-Lescor, J.F., Lavabre, J., Folton, N., Mathys, N., Richard, D. 2005. The hydrological impact of the Mediterranean forest: a review of French research. Journal of Hydrology 301, 235-249.

De Alba, S., Benito, G., Pérez-González, A. 1998. Erosión del suelo en episodios de lluvia de elevada intensidad versus episodios de moderada y baja intensidad y elevada frecuencia en ambientes semiáridos. In: A. Gómez-Ortiz, F. Salvador, L. Schulte and A. García-Navarro (Eds.), Investigaciones recientes de la geomorfología española, Sociedad Española de Geomorfología, Granada, pp. 483-491.

De Graaf, J., Eppink, L.A.A.J. 1999. Olive oil production and soil conservation in southern Spain, in relation to EU subsidy policies. Land Use Policy 16, 259-267.

De Luís, M., González-Hidalgo, J.C., Longares, L.A. 2010. Is rainfall erosivity increasing in the Iberian Peninsula? Land Degradation and Development 21, 139-144.

De Santisteban, L.M., Casalí, J., López, J.J. 2006. Assessing soil erosion rates in cultivated areas of Navarre (Spain). Earth Surface Processes and Landforms 31, 487506.

De Vente, J., Poesen, J. 2005. Predicting soil erosion and sediment yield at the basin scale: Scale issues and semi-quantitative models. Earth-Science Reviews 71, 95-125.

De Vente, J., Poesen, J., Arabkhedri, M., Verstraeten, G. 2007. The sediment delivery problem revisited. Progress in Physical Geography 31 (2), 155-178.

Enne, G., Pulina, G., D’Angelo, M., Previtali, F., Madrau, S., Caredda, S., Francesconi, A.H.D. 2002. Agropastoral activities and land degradation in Mediterranean areas. Case study of Sardinia. In: N.A. Geeson, C.J. Brandt and J.B. Thornes (Eds.), Mediterranean desertification: A mosaic of processes and responses. Wiley, Chichester, pp. 71-81. 
Faulkner, H. 1995. Gully erosion associates with the expansion of unterraced almond cultivation in the coastal Sierra de Lújar, S. Spain. Land Degradation and Rehabilitation 6, 179-200.

Gabert, P., Nicod, J. 1982. Inondations and urbanisation en milieu méditerranéen. L'example des crues récentes de l'Arc et de l'Huveaune. Méditerranée 3, 11-24.

Gallart, F. 2009. Algunos criterios topográficos para identificar el origen antrópico de cárcavas. Cuadernos de Investigación Geográfica 35 (2), 215-221.

Gallart, F., Llorens, P. 2004. Observations on land cover changes and water resources in the headwaters of the Ebro catchment, Iberian Peninsula. Physics and Chemistry of the Earth 29, 769-773.

Gallart, F., Llorens, P., Latron, J. 1994. Studying the role of old agricultural terraces on runoff generation in a small Mediterranean mountainous basin. Journal of Hydrology 159, 291-303.

Gallart, F., Solé, A., Puigdefábregas, J., Lázaro, R. 2002. Badland systems in the Mediterranean. In: L.J. Bull and M.J. Kirkby, eds., Dryland rivers: Hydrology and Geomorphology of semi-arid channels. Wiley, Chichester, pp. 299-326.

Gallart, F., Marignani, M., Pérez-Gallego, N., Santi, E., Maccherini, S. 2012. Thirty years of studies on badlands, from physical to vegetated approaches. A succinct review. Catena 106, 4-11.

García-Ruiz, J.M. 1999. La producción científica de la geomorfología española y su impacto, a través de las publicaciones periódicas. Instituto Pirenaico de Ecología, Zaragoza, $104 \mathrm{pp}$.

García-Ruiz, J.M. 2010. The effects of land uses on soil erosion in Spain: A review. Catena 81, 1-11.

García-Ruiz, J.M., López-Bermúdez, F. 2009. La erosión del suelo en España. Sociedad Española de Geomorfología, Zaragoza, 441 pp.

García-Ruiz, J.M., Lana-Renault, N. 2011. Hydrological and erosive consequences of farmland abandonment in Europe, with special reference to the Mediterranean region. A review. Agriculture, Ecosystems \& Environment 140, 317-338.

García-Ruiz, J.M., Lasanta, T., Alberto F. 1997. Soil erosion by piping in irrigated fields. Geomorphology 20, 269-278.

García-Ruiz, J.M., López-Moreno, J.I., Vicente-Serrano, S., Lasanta-Martínez, T., Beguería, S. 2011. Mediterranean water resources in a global change scenario. EarthScience Reviews 105, 121-139. 
García-Ruiz, J.M., Lana-Renault, N., Beguería, S., Lasanta, T., Regüés, D., NadalRomero, E., Serrano-Muela, P., López-Moreno, J.I., Alvera, B., Martí-Bono, C., Alatorre, L.C. 2010. From plot to regional scales: Interactions of slope and catchment hydrological and geomorphic processes in the Spanish Pyrenees. Geomorphology 120, 248-257.

Garfi, G., Bruno, D.E., Calcaterra, D., Parise, M. 2007. Fan morphodynamics and slope instability in the Mucana River basin (Sila Massif, southern Italy): significance of weathering and role of land use changes. Catena 69, 181-196.

Gaume, E., Bain, V., Bernardara, P., Newinger, O., Barbuc, M., Bateman, A., Blaskovikova, L., Bloschl, G., Borga, M., Dumitrescu, A., Daliakopoulos, I., García, J., Irimescu, A., Kohnova, S., Koutroulis, A., Marchi, L., Matreata, S., Mwedina, V., Preciso, E., Sempere-Torres, D., Stancalie, G., Szolgay, J., Tsanis, I., Velasco, D., Viglione, A. 2009. A compilation of data on European flash floods. Journal of Hydrology 367, 70-78.

Geeson, N.A., Brandt, C.J., Thornes, J.B. (eds.) 2002. Mediterranean Desertification. A Mosaic of Processes and Responses. John Wiley, Chichester, 440 pp.

Gil-Romera, G., Carrión, J.S., Pausas, J.G., Sevilla-Callejo, M., Lamb, H.F., Fernández, S., Burjachs, F. 2010. Holocene fire activity and vegetation response in SouthEastern Iberia. Quaternary Science Reviews 29, 1082-1092.

Gil-Olcina, A. 2007. Mediterranean and subtropical climatic elements. Boletín de la Asociación de Geógrafos Españoles 44, 351-354.

Gimeno, E., Andreu, V., Rubio, J.L. 2000. Changes in organic matter, nitrogen, phosphorus and cations in soil as a result of fire and water erosion in a Mediterranean landscape. European Journal of Soil Science 51, 201-210.

Gimeno-García, E., Andreu, V., Rubio, J.L. 2007. Influence of vegetation recovery on water erosion at short and medium-term after experimental fires in a Mediterranean shrubland. Catena 69, 150-160.

Gómez-Urdáñez, J.L. 1986. Subsistencia y descapitalización en el Camero Viejo al final del Antiguo Régimen. Cuadernos de Investigación Histórica 12, 103-140.

Gómez-Villar, A., García-Ruiz, J.M. 2000. Surface sediment characteristics and present dynamics in alluvial fans of the Central Spanish Pyrenees. Geomorphology 34, 127 144. 
Gómez-Villar, A., Álvarez-Martínez, J., García-Ruiz, J.M. 2006. Factors influencing the presence or absence of tributary-junction fans in the Iberian Range, Spain. Geomorphology 81, 252-264.

Gónzález-Hidalgo, J.C., Peña-Monné, J.L., De Luís, M. 2007. A review of daily soil erosion in Western Mediterranean areas. Catena 71, 193-199.

Grove, A.T. 2001. The "Little Ice Age" and its geomorphological consequences in the Mediterranean Europe. Climatic Change 48, 121-136.

Grove, A.T., Rackham, O. 2001. The nature of Mediterranean Europe. An ecological history. Yale University Press, London, 348 pp.

Gutiérrez-Elorza, M., Peña-Monné, J.L. 1998. Geomorphology and late Holocene climatic change in Northeastern Spain. Geomorphology 23, 205-217.

Harvey, A.M., Gutiérrez-Elorza, M. 2005. Repeated patterns of Quaternary discontinuous gullying at El Tormillo, Ebro Basin, Spain. In: C. García and R.J. Batalla (Eds.), Catchment dynamics and river processes. Mediterranean and other climate regions, Elsevier, Amsterdam, pp. 52-67.

Hill, J., Stellmes, M., Undelhoven, Th., Röder, A., Sommer, S. 2008. Mediterranean desertification and land degradation. Mapping related land use change syndromes based on satellite observations. Global and Planetary Change 64, 146-157.

Hooke, J.M. 2006. Human impacts on fluvial systems in the Mediterranean region. Geomorphology 79, 311-335.

Jebari, S., Berndtsson, R., Bahri, A., Boufaroua, M. 2010. Spatial soil loss risk and reservoir siltation in semi-arid Tunisia. Hydrological Sciences Journal 55, 121-137.

Keestra, S.D., Van Huissteden, J., Vandenberghe, J., Van Dam, O., De Gier, J., Pleizier, I.D. 2005. Evolution of the morphology of the river Dragonja (SW Slovenia) due to land-use changes. Geomorphology 69, 191-207.

Kirkby, M.J., Bracken, L., Reaney, S. 2002. The influence of land use, soils and topography on the delivery of hillslope runoff to channel in SE Spain. Earth Surface Processes and Landforms 27, 1459-1473.

Kizos, T., Koulouri, 2006. Agricultural landscape dynamics in the Mediterranean: Lesvos (Greece) case study using evidence from the last three centuries. Environmental Science \& Policy 9, 330-342.

Koulouri, M., Giourga, C. 2007. Land abandonment and slope gradient as key factors of soil erosion in Mediterranean terraced lands. Catena 69, 274-281. 
Kosmas, C., Gerontidis, S., Marathianoy, M. 2000. The effect of land use change on soils and vegetation over various lithological formations on Lesvos (Greece). Catena $40,51-68$.

Kosmas, C., Danalatos, N.G., López-Bermúdez, F., Romero-Díaz, M.A. 2002. The effect of land use on soil erosion and land degradation under Mediterranean conditions. In N.A. Geeson, C.J. Brandt, J.B. Thornes (Eds.), Mediterranean desertification: A mosaic of processes and responses, John Wiley, Chichester, pp. $57-70$.

Kosmas, C., Danalatos, N., Cammeraat, L.H., Chabart, M., Diamantopoulos, J., Farand, R., Gutiérrez, L., Jacob, A., Marques, H., Martínez-Fernández, J., Mizara, A., Moutakas, N., Nicolau, J.M., Oliveros, C., Pinna, G., Puddu, R., Puigdefábregas, J., Roxo, M., Simao, A., Stamou, G., Tomasi, N., Usaai, D., Vacca, A. 1997. The effect of land use on runoff and soil erosion rates under Mediterranean conditions. Catena 29, 45-59.

Lahlou, A. 1996. Environmental and socio-economic impacts of erosion and sedimentation in North Africa. IAHS Publ. 236, 491-500.

Lana-Renault, N., Regüés, D. 2009. Seasonal patterns of suspended sediment transport in an abandoned farmland catchment in the Central Spanish Pyrenees. Earth Surface Processes and Landforms 34, 1291-1301.

Lana-Renault, N., Latron, J., Karssenberg, D., Serrano, P., Regüés, D., Bierkens, M.F.P. 2011. Differences in stream flow in relation to changes in land cover: a comparative study in two sub-Mediterranean mountain catchments. Journal of Hydrology 411, 366-378.

Lario, J., Zazo, C., Dabrio, C.J., Somoza, L., Goy, J.L., Bardají, T., Silva, P.G. 1995. Record of recent sediment inputs on spot bars and deltas of south Spain. Journal of Coastal Research 17, 241-245.

Lasanta, T., Arnáez, J., Oserín, M., Ortigosa, L. 2001. Marginal lands and erosion in terraced fields in the Mediterranean mountains: a case study in the Camero Viejo (Northwestern Iberian System, Spain). Mountain Research and Development 21 (1), 69-76.

Lasanta, T., Arnáez, J., Errea, M.P., Ortigosa, L., Ruiz-Flaño, P. 2009. Mountain pastures, environmental degradation, and landscape remediation: The example of a Mediterranean policy initiative. Applied Geography 29, 308-319. 
Lasheras-Álvarez, L., Pérez-Sanz, A., Gil-Romera, G., González-Sampériz, P., SevillaCallejo, M., Valero-Garcés, B. 2013. Historia del fuego y la vegetación en una secuencia holocena del Pirineo Central: la Basa de la Mora. Cuadernos de Investigación Geográfica 39 (1), 77-95.

Latron, J., Llorens, P., Gallart, F. 2009. The hydrology of Mediterranean mountain areas. Geography Compass 3-6, 2045-2064.

Lázaro, R., Cantón, Y., Solé-Benet, A., Bevan, J., Alexander, R., Sancho, L.G., Puigdefábregas, J. 2008. The influence of competition and erosion on the evolution of soil surfaces in the Tabernas badlands (SE Spain) and its landscape effects. Geomorphology 102, 252-266.

Le Lay, M., Saulnier, G.M. 2007. Exploring the signature of climate and spatial variabilities in flash flood events: Case of the 8-9 September 2002 CevennesViverais catastrophic event. Geophysical Research Letters 34 (13) L13401, doi:10.1029/2007GL029746.

Lesschen, J.P., Cammeraat, L.H., Nieman, T. 2008. Erosion and terrace failure due to agricultural land abandonment in a semi-arid environment. Earth Surface Processes and Landforms 33, 1574-1584.

Lesschen, J.P., Kok, K., Verburg, P.H., Cammeraat, L.H. 2007. Identification of vulnerable areas for gully erosion under different scenarios of land abandonment in Southeast Spain. Catena 71, 110-121.

Liébault, F., Piégay, H. 2001. Assessment of channel changes due to long-term bedload supply decrease. Roubion River, France. Geomorphology 36, 167-186.

Liébault, F., Piégay, H. 2002. Causes of the 20th century narrowing in mountain and piedmont rivers of southeastern France. Earth Surface Processes and Landforms 27, 425-444.

Llasat, M.C., Puigcerver, M. 1992. Pluie extreme en Catalogne. Influences orographiques et caractéristiques synoptiques. Hydrologie Continentale 7, 99-115.

Llorens, P., Queralt, I., Plana, F., Gallart, F. 1997. Studying solute and particulate sediment transfer in a small Mediterranean mountainous catchment subject to land abandonment. Earth Surface Processes and Landforms 22, 1027-1035.

López-Bermúdez, F. 2008. Desertificación: Preguntas y respuestas a un desafío económico, social y ambiental. Fundación Biodiversidad, Madrid, 129 pp. 
López-Bermúdez, F., Romero-Díaz, M.A. 1993. Génesis y consecuencias erosivas de las lluvias de alta intensidad en la region mediterránea. Cuadernos de Investigación Geográfica 18-19, 7-28.

López-Tarazón, J.A., Batalla, R.J., Vericat, D., Francke, T. 2009. Suspended sediment transport in a highly erodible catchment: The River Isábena (Southern Pyrenees): Geomorphology 109, 210-221.

López-Tarazón, J.A., Batalla, R.J., Vericat, D., Francke, T. 2012. The sediment budget of a highly dynamic mesoscale catchment: The River Isábena. Geomorphology 138, $15-28$.

Maccherini, S., Marignani, M., Gloria, M., Renzi, M., Rocchini, D., Santi, E., Torri, D., Tundo, J., Honnay, O. 2011. Determinants of plant community composition of remnant biancana badlands: a hierarchical approach to quantify species-environment relationships. Applied Vegetation Science 14, 378-387.

Machado, M.J., Benitio, G., Barriendos, M., Rodrigo, F.S. 2011. 500 years of rainfall variability and extreme hydrological events in southeastern Spain drylands. Journal of Arid Environments 75, 1244-1253.

Maher, E., Harvey, A.M. 2008. Fluvial system response to tectonically induced baselevel change during the late-Quaternary: The Río Alias southeast Spain. Geomorphology 100, 180-192.

Mairota, P., Thornes, J.B., Geeson, N. (eds.) 1998. Atlas of Mediterranean environments in Europe: The desertification context. John Wiley, Chichester.

Malvárez, G., Lario, J., Zazo, C., Goy, J.L., Luque, L. 1998. Evolución de la costa de Málaga durante el Pleistoceno Superior y Holoceno y morfodinámica actual de los sistemas litorales. In: A. Gómez-Ortiz, F. Salvador, L. Schulte and A. GarcíaNavarro (Eds.), Itinerarios geomorfológicos por Andalucía Oriental, Universitat de Barcelona, Barcelona, pp. 9-28.

Margaris, N.S., Koutsidou, E. 2002. Landscape protection from grazing and fire. In: N.A. Geeson, C.J. Brandt, J.B. Thornes (Eds.), Mediterranean desertification. A mosaic of processes and responses. Wiley, Chichester, pp. 83-92.

Martí-Bono, C., Puigdefábregas, J. 1983. Consecuencias geomorfológicas de las lluvias de noviembre de 1982 en las cabeceras de algunos valles pirenaicos. Estudios Geográficos 170-171, 275-289. 
Martínez-Fernández, J., López-Bermúdez, F., Martínez-Fernández, J., Romero-Díaz, A. 1995. Land use and soil-vegetation relationships in a Mediterranean ecosystem. Catena 25, 153-167.

Mateu-Bellés, J. 1988. Crecidas e inundaciones en el Pais Valenciano. In: Guía de la naturaleza de la Comunidad Valenciana. Edicions Alfons el Manànim, Diputación Provincial de Valencia, Valencia, pp. 596-636.

Mathys, N., Klotz, S., Esteves, M., Descroix, L., Lapetite, J.M. 2005. Runoff and erosion in the Black marls of the French Alps: observations and measurements at the plot scale. Catena 63, 261-281.

Maurer, G. 1992. Agriculture in the Rif and Tell mountains of North Africa. Mountain Research and Development 12 (4), 337-347.

Meerkerk, A.L., Van Wesemaeel, B., Bellin, N. 2009. Application of connectivity theory to model the impact of terrace failure on runoff in semi-arid catchments. Hydrological Processes 23, 2792-2803.

Mohammad, A.G., Adam, M.A., 2010. The impact of vegetative cover type on runoff and soil erosion under different land uses. Catena 81, 97-103.

Montserrat, J. 1972. Evolución glaciar y postglaciar del clima y la vegetación en la vertiente sur del Pirineo: Estudio palinológico. Instituto Pirenaico de Ecología, Zaragoza, $147 \mathrm{pp}$.

Morán-Tejeda, E., Ceballos-Barbancho, A., Llorente Pinto, J.M. 2010. Hydrological response of Mediterranean headwater to climate oscillations and land-cover changes: the mountains of Duero River basin (Central Spain). Global and Planetary Change 72, $39-49$.

Nadal-Romero, E. 2011. Las áreas de cárcavas (badlands) como fuente de sediment en cuencas de montaña: procesos de meteorización, erosión y transporte en margas del Pirineo Central. Publicaciones del Consejo de Protección de la Naturaleza en Aragón, Zaragoza, 377 pp.

Nadal-Romero, E., Regüés, D., Martí-Bono, C., Sertrano-Muela, P. 2007. Badland dynamics in the Central Pyrenees: temporal and spatial patterns of weathering processes. Earth Surface Processes and Landforms 32, 888-904.

Nadal-Romero, E., Latron, J., Martí-Bono, C., Regüés, D. 2008. Temporal distribution of suspended sediment transport in a humid Mediterranean badland area: The Araguás catchment, Central Pyrenees. Geomorphology 97, 601-616. 
Nadal-Romero, E., Martínez-Murillo, J.F., Vanmaercke, M., Poesen, J. 2011. Scaledependency of sediment yield from badland areas in Mediterranean environments. Progress in Physical Geography 35 (3), 297-332.

Nadal-Romero, E., Lasanta, T., González-Hidalgo, J.C., De Luís, M., García-Ruiz, J.M. 2012a. The effect of intense rainstorm events on the suspended sediment response of land under various land uses: The Aísa Valley Experimental Station. Cuadernos de Investigación Geográfica 38 (1), 27-47.

Nadal-Romero, E., Lasanta, T., García-Ruiz, J.M. 2012b. Runoff and sediment yield from land under various uses in a Mediterranean mountain area: long term results from an experimental station. Earth Surface Processes and Landforms, 38, 346-355.

Nadal-Romero, E., Vicente-Serrano, S.M., Jiménez, I. 2012c. Assessment of badland dynamics using multitemporal Landsat imagery: An example from the Spanish PrePyrenees. Catena 96, 1-11.

Nadal-Romero, E., Martínez-Murillo, J.F., Vanmaercke, M., Poesen J. 2012d. Corrigendum to "Scale dependency of sediment yield from badland areas in Mediterranean environments". Progess in Physical Geography, doi: $10.1177 / 0309133312447025$.

Navas, A., Valero-Garcés, B., Gaspar, L., Palazón, L. 2011. Radionuclides and stable elements in the sediments of the Yesa Reservoir, Central Spanish Pyrenees. Journal of Soil and Sediments 11, 1082-1098.

Nieto, R., Gimeno, L., de la Torre, L., Ribera, P., Gallego, D., García-Herrera, R., García, J.A., Lorente, J. 2005. Climatological features of cutoss low systems in the Northern Hemisphere. Journal of Climate 18, 3085-3103.

Novara, A., Gristina, L., Saladino, S.S., Santoro, A., Cerdà, A. 2011. Soil erosion assessment on tillage and alternative soil managements in a Sicilian vineyard. Soil \& Tillage Research 117, 140-147.

Oliver, J.E., edr. 2005. Encyclopedia of World Climatology. Springer, Berlin, 854 pp.

Oostwoud Wijdenes, D.J., Poesen, J., Vandekerckhove, L., Nachtergaele, J., De Baerdemaeker, J. 1999. Gully-head morphology and implications for gully development on abandoned fields in a semi-arid environment, Sierra de Gata, Southeast Spain. Earth Surface Processes and Landforms 24, 585-603.

Ortega, J.A., Garzón Heydt, G. 2009. Geomorphological and sedimentological analysis of flash-flood deposits. The case of the 1997 Rivillas flood (Spain). Geomorphology $112,1-14$. 
Pardini, G., Gispert, M. 2006. Impact of land abandonment on water erosion in soils of the Iberian Peninsula. Agrochimica 50, 13-24.

Pardini, G., Gispert, M. 2012. Soil quality assessment through a multi-approach analysis in soils of abandoned terraced land in NE Spain. Cuadernos de Investigación Geográfica 38 (2), 7-30.

Peña, J.L., De Dapper, M., De Vliegher, B.M. 1995. Acumulaciones holocenas y geoarqueología en el sur de la isla de Eubea (Grecia). Geographicalia 32, 155-169.

Peña, J.L., Echeverría, M.T., Julián, A., Chueca, J. 2000. Processus d'accumulation et d'incision pendant l'Antiquité Classique dans la vallée de la Huerva (Bassin de l'Ebre, Espagne). In: F. Vermeulen and M. De Dapper (Eds.), Geoarchaeology of the Landscapes of Classical Antiquity, Babesch, London, pp. 151-159. 2000

Poesen, J., Lavee, H. 1994. Rock fragments in top soils: significance and processes. Catena 23, 1-28.

Poesen, J., Ingelmo-Sánchez, F. 1992. Runoff and sediment yield from topsoils with different porosity as affected by rock fragments cover and position. Catena 19, 451474.

Poesen, J.W.A., Hooke, J.M. 1997. Erosion, flooding and channel management in Mediterranean environments of southern Europe. Progress in Physical Geography 21 (2), 157-199.

Puigdefábregas, J., Mendizábal, T. 1998. Perspectives on desertification: western Mediterranean. Journal of Arid Environments 39, 209-224.

Quiñonero-Rubio, J.M., Boix-Fayos, C., de Vente, J. 2013. Desarrollo y aplicación de un índice multifactorial de conectividad de sedimentos a escala de cuenca. Cuadernos de Investigación Geográfica 39 (2), 213-233.

Ramos, M.C., Martínez-Casasnovas, J.A. 2006a. Nutrient losses by runoff in vineyards of the Mediterranean Alt Penedès region (NE Spain). Agriculture, Ecosystems \& Environment 113, 356-363.

Ramos, M.C., Martínez-Casasnovas, J.A. 2006b. Impact of land levelling on soil moisture and runoff variability in vineyards under different rainfall distributions in a Mediterranean climate and its influence on crop productivity. Journal of Hydrology 321, 131-146.

RECONDES 2007. Combatiendo la degradación de tierras con técnicas de minima intervención: La estrategia de reducción de la conectividad. University of Portsmouth, Portsmouth, $21 \mathrm{pp}$. 
Regüés, D., Nadal-Romero, E., Latron, J., Martí-Bono, C. 2009. Producción y transporte de sedimento en cárcavas desarrolladas en la Depresión Interior Altoaragonesa (Cuenca de Araguás, Pirineo Central). Cuadernos de Investigación Geográfica 35 (2), 263-287.

Rico-Amorós, A.M., Olcina-Cantos, J., Saurí, D. 2009. Tourist land use pattern and water demand. Evidence from the Western Mediterranean. Land Use Policy 26, 493501.

Ries, J.B., Langer, M. 2001. Runoff generation of abandoned fields in the central Ebro Basin. Results from rainfall simulation experiments. Cuadernos de Investigación Geográfica 27, 61-78.

Rius, D., Vannière, B., Galop, D. 2011. Holocene history of fire, vegetation and land use from the central Pyrenees (France). Quaternary Research 77, 54-64.

Romero-Díaz, A., Belmonte-Serrato, F., Ruiz-Sinoga, D. 2010. The geomorphic impact of afforestation on soil erosion in southeast Spain. Land Degradation and Development 21, 188-195.

Romero-Díaz, A., Marín-Sanleandro, P., Sánchez-Soriano, A., Belmonte-Serrato, F., Faulkner, H. 2007. The causes of piping in a set of abandoned agricultural terraces in Southeast Spain. Catena 69, 282-293.

Ruecker, G., Schad, P., Alcubilla, M.M., Ferrer, C. 1998. Natural regeneration of degraded soils and site changes on abandoned agricultural terraces in Mediterranean Spain. Land Degradation and Development 9, 179-188.

Ruiz, J.M., Carmona, P. 2005. La llanura deltaica de los ríos Júcar y Turia y la Albufera de Valencia. In: E. Sanjaume and J. Mateu (Eds.), Geomorfología litoral i Quaternari. Homenatge al Prof. V.M. Rosselló, Universidad de Valencia, Valencia, pp. 399-418.

Ruiz-Flaño, P., García-Ruiz, J.M., Ortigosa, L. 1992. Geomorphological evolution of abandoned fields. A case study in the Central Pyrenees. Catena 19, 301-308.

Ruiz-Flaño, P., Arnáez, J., Ortigosa, L., Lasanta, T. 2006. Organización especial de procesos de erosión en laderas cultivadas con viñedos en La Rioja como consecuencia de precipitaciones intensas. In: A. Pérez-Alberti and J. López-Bedoya (Eds.), Geomorfología y territorio, Universidade de Santiago de Compostela, Santiago de Compostela, pp. 247-256.

Sala, M., Inbar, M. 1992. Some hydrologic effects of urbanization in Catalan rivers. Catena 19, 363-378. 
Salvati, L., Bajocco, S. 2011. Land sensitivity to desertification across Italy. Past, present and future. Applied Geography 31, 223-231.

Sancho, C., Peña, J.L., Muñoz, A., Benito, G., McDonald, E., Rhodes, E.J., Longares, L.A. 2008. Holocene alluvial morphosedimentary record and environmental changes in the Bardenas Reales Natural Park (NE Spain). Catena 73, 225-238.

Seeger, M., Ries, J.B. 2008. Soil degradation and soil surface process intensities on abandoned fields in Mediterranean mountain environments. Land Degradation \& Development 19, 488-501.

Serrano-Muela, M.P., Nadal-Romero, E., Lana-Renault, N., González-Hidalgo, J.C., López-Moreno, J.I., Beguería, S., Sanjuan, Y., García-Ruiz, J.M. 2013. An exceptional rainfall event in the central western Pyrenees: spatial patterns in discharge and impact. Land Degradation \& Development, doi: 10.1002/ldr.2221

Shakesby, R.A. 2011. Post-wildfire soil erosion in the Mediterranean: Review and future research directions. Earth-Science Reviews 105, 71-100.

Shakesby, R.A., Doerr, S.H. 2006. Wildfire as a hydrological and geomorphological agent. Earth-Science Reviews 74, 269-307.

Sougnez, N., Van Wesemael, B., Vanacker, V. 2011. Low erosion rates measured for steep, sparsely vegetated catchments in southeast Spain. Catena 84, 1-11.

Stahl, K., Hisdal, H., Hannaford, J., Tallasken, L.M., Van Lanen, H.A.J., Sauquet, E., Demuth, S., Fendekova, M., Jódar, J. 2010. Streamflow trends in Europe: evidence from a dataset of near-natural catchments. Hydrology and Earth System Sciences 14, 2367-2382.

Surian, S., Rinaldi, M., Pellegrini, L., Audisio, C., Moraga, F., Teruggi, L., Turitto, O., Ziliani, L. 2010. Channel adjustments in northern and central Italy over the last 200 years. Geological Society of America Special Papers 451, 83-95.

Tena, A., Batalla, R.J., Vericat, D., López-Tarazón, J.A. 2011. Suspended sediment dynamics in a large regulated river over a 10-year period (the Lower Ebro, NE Iberian Peninsula). Geomorphology 125, 73-84.

Thornes, J.B. 1976. Semi-arid erosional systems. Occasional Paper 7, London, School of Economics.

Thornes, J.B. 2002. The evolving context of Mediterranean desertification. In N.A. Geeson, C.J. Brandt, J.B. Thornes (Eds.), Mediterranean Desertification: A Mosaic of Processes and Responses. John Wiley, Chichester, pp. 5-11. 
Trimble, S.W. 1990. Geomorphic effects of vegetation cover and management: some time and space considerations in prediction of erosion and sediment yield. In: J.B. Thornes (Ed.), Vegetation and Erosion, Processes and Environments. Wiley, Chichester, pp. 55-66.

Úbeda, X., Bernia, S., Simelton, E. 2005. The long-term effects on soil properties from a forest fire of varying intensity in a Mediterranean environment. In: C. García and R.J. Batalla (Eds.), Catchment Dynamics and River Processes: Mediterranean and Other Climate Regions. Elsevier, Amsterdam, pp. 87-102.

Van Andel, T.H., Runnels, C.N., Pope, K.O. 1986. 5000 years of land use and abuse in the southern Argolid, Greece. Hesperia 55, 103-128.

Van Wesemael, B., Rambaud, X., Poesen, J., Muligan, M., Cammeraat, E., Stevens, A. 2006. Spatial patterns of land degradation and their impacts on the water balance of rainfed tree crops: A case study in South East Spain. Geoderma 133, 43-56.

Vanmaercke, M., Poesen, J., Verstraeten, G., De Vewnte, J., Ocakoglu, F. 2011. Sediment yield in Europe: Spatial patterns and scale dependency. Geomorphology $130,142-161$.

Vannière, B., Power, M.J., Roberts, N., Tinner, W., Carrión, J., Magny, M., Bartlein, P., Colombaroli, D., Daniau, A.L., Finsinger, W., Gil-Romera, G., Kaltenrieder, P., Pini, R., Sadori, L., Turner, R., Valsecchi, V., Vescovi, E. 2011. Circum-Mediterranean fire activity and climate changes during the mid-Holocene environmental transition (8500-2500 cal. BP). The Holocene 21 (1), 53-73.

Vicente-Serrano, S.M., Cuadrat-Prats, J.M. 2007. Trends in drought intensity and variability in the middle Ebro Valley (NE Spain) during the second half of the twentieth century. Theoretical and Applied Climatology 88, 247-258.

Vita-Finzi, C. 1969. The Mediterranean valleys. Geological changes in historical times. Cambridge University Press, Cambridge, 140 pp.

Wainwright, J., Thornes, J.B. 2004. Environmental issues in the Mediterranean. Processes and perspectives from the past and present. Routledge, London, $479 \mathrm{pp}$.

White, S.M., García-Ruiz, J.M. 1998. Extreme erosional events and their role in mountain areas of northern Spain. Ambio 27 (4), 300-305.

White, S., García-Ruiz, J.M., Martí, C., Valero, B., Errea, M.P., Gómez-Villar, A. 1997. The 1996 Biescas campsite disaster in the Central Spanish Pyrenees, and its temporal and spatial context. Hydrological Processes 11, 1797-1812. 
Wise, S.M., Thornes, J.B., Gilman, A. 1982. How old are the badlands? A case study from south east Spain. In: R.B. Bryan and A. Yair (Eds.), Badland Geomorphology and Piping, GeoBooks, Norwich, pp. 259-277.

Wittenberg, L., Inbar, M. 2009. The role of fire disturbance on runoff and erosion processes - A long-term approach, Mt. Carmel case study, Israel. Geographical Research 47, 46-56.

Wittenberg, L., Kutiel, H., Greenbaum, N., Inbar, M. 2007. Short-term changes in the magnitude, frequency and temporal distribution of floods in the Eastern Mediterranean region during the last 45 years - Nahal Oren, Mt. Carmel, Israel. Geomorphology 84, 181-191.

Yair, A., Lavee, H., Bryan, R.B., Adar, E. 1980. Runoff and erosion processes and rates in the Zin valley, Northern Negev, Israel. Earth Surface Processes 5, 205-225.

\section{FIGURE CAPTIONS}

Fig. 1. Distribution of soil erosion studies by country.

Fig. 2. Distribution of studies of soil erosion according to different study topics.

Fig. 3. Evolution of the most important study topics.

Fig. 4. The distribution of study topics by country.

Fig. 5. The methods used in the study of soil erosion in the Mediterranean region.

Fig. 6. The Mediterranean region in Europe, Near-East and North Africa.

Fig. 7. Mean temperature and precipitation for various weather stations in the Mediterranean region.

Fig. 8. Variability of erosion rates for various land cover/land uses in the Mediterranean region. Black dots correspond to erosion rates obtained from experimental plots, and crosses from experimental catchments. 


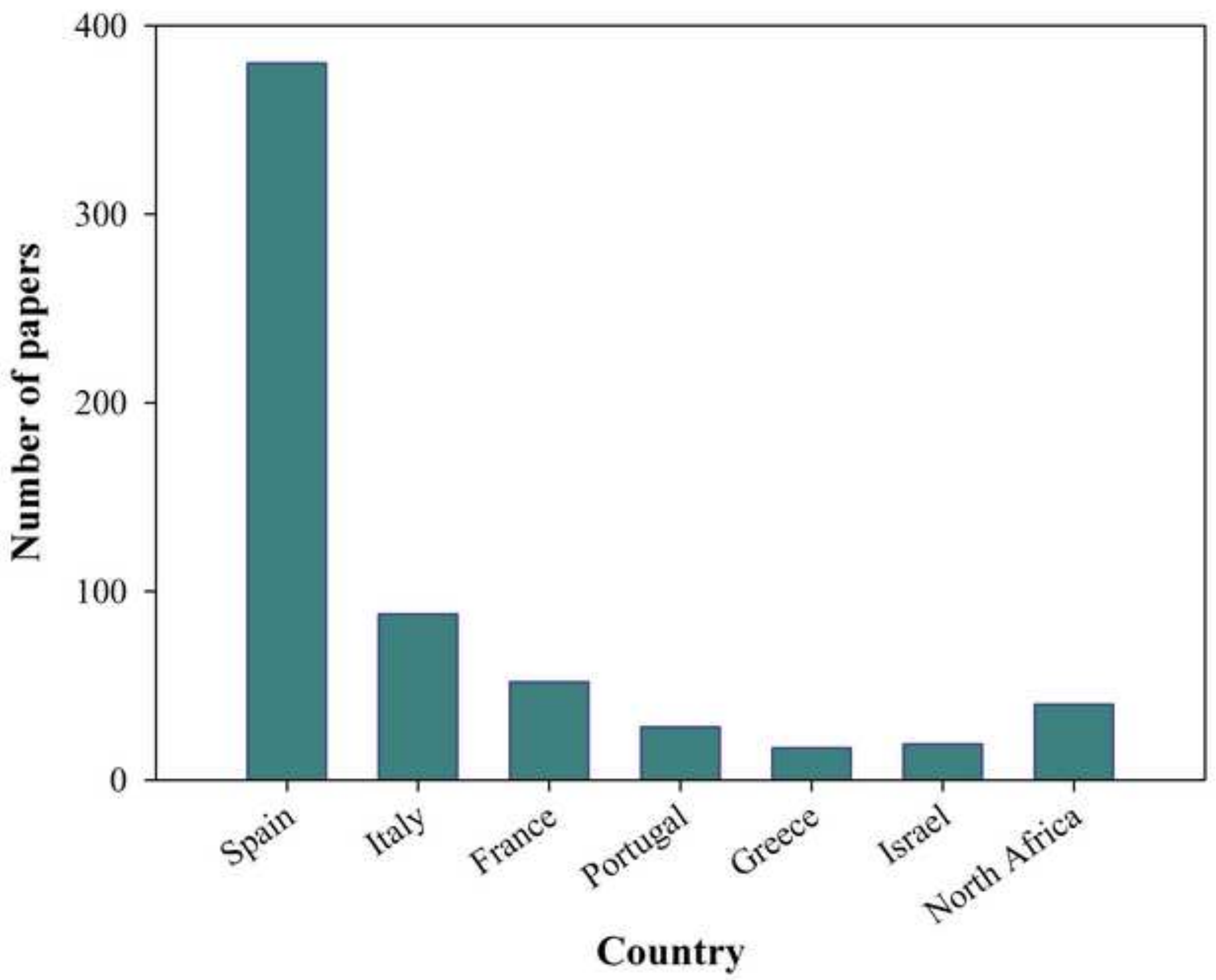




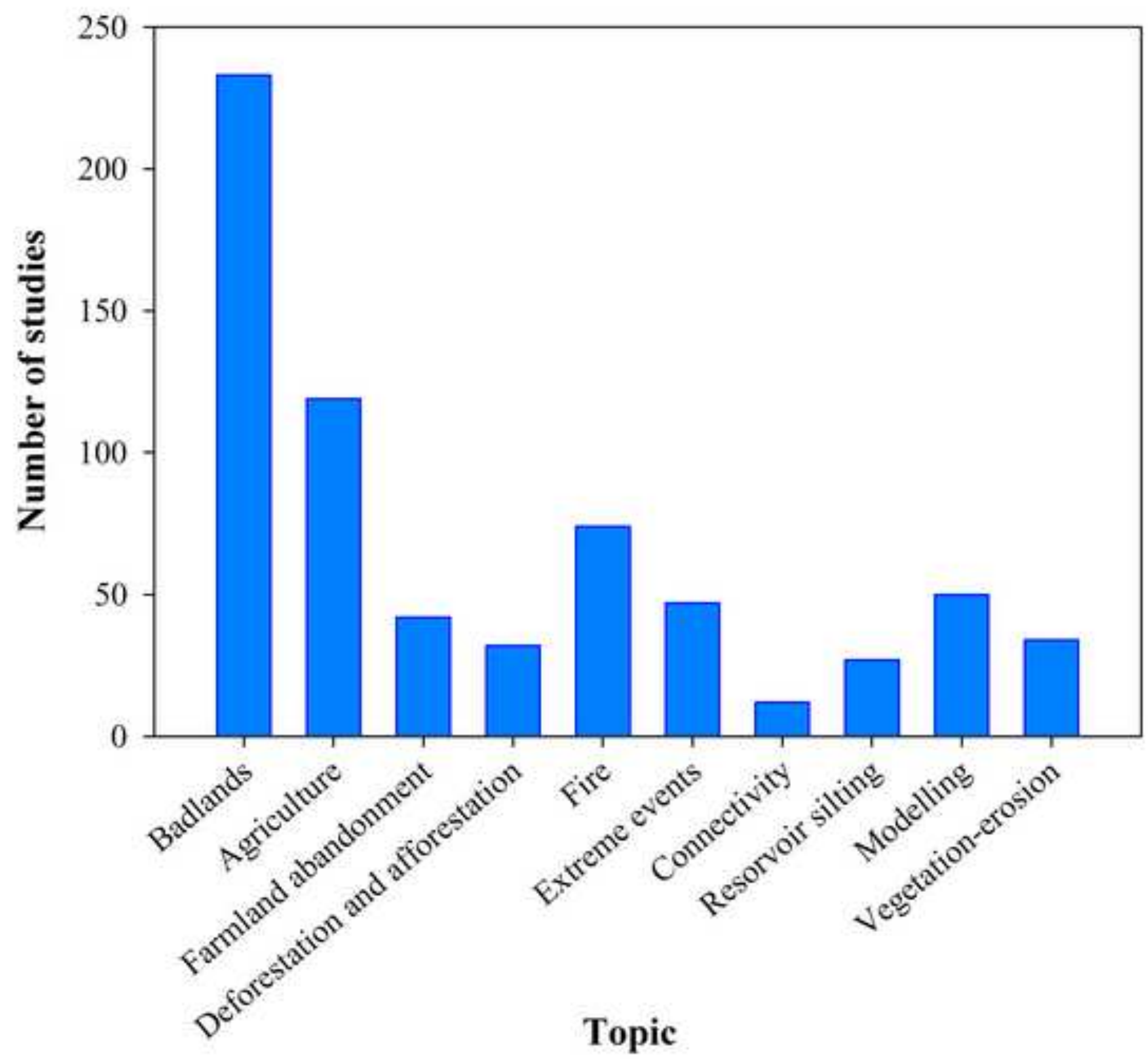




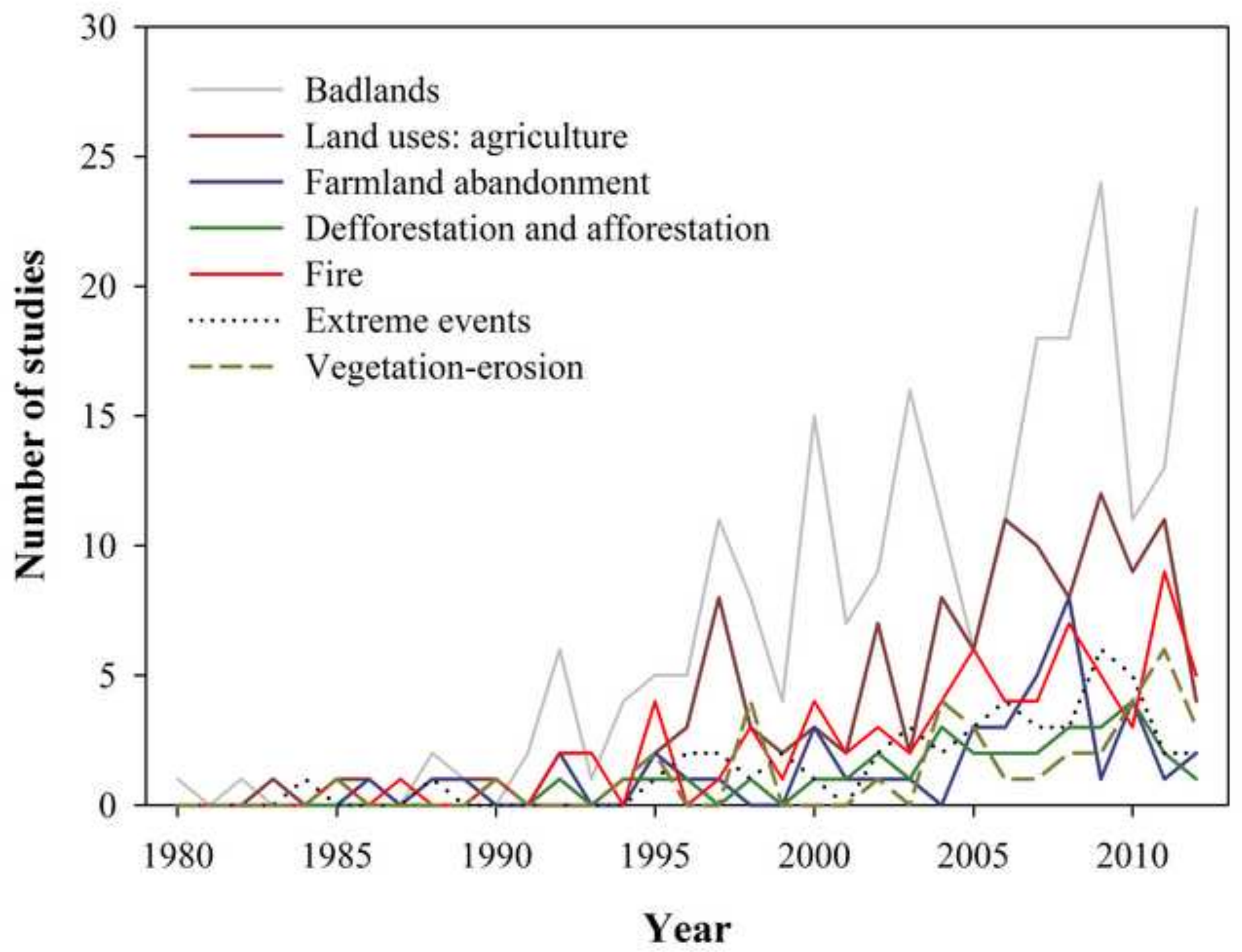



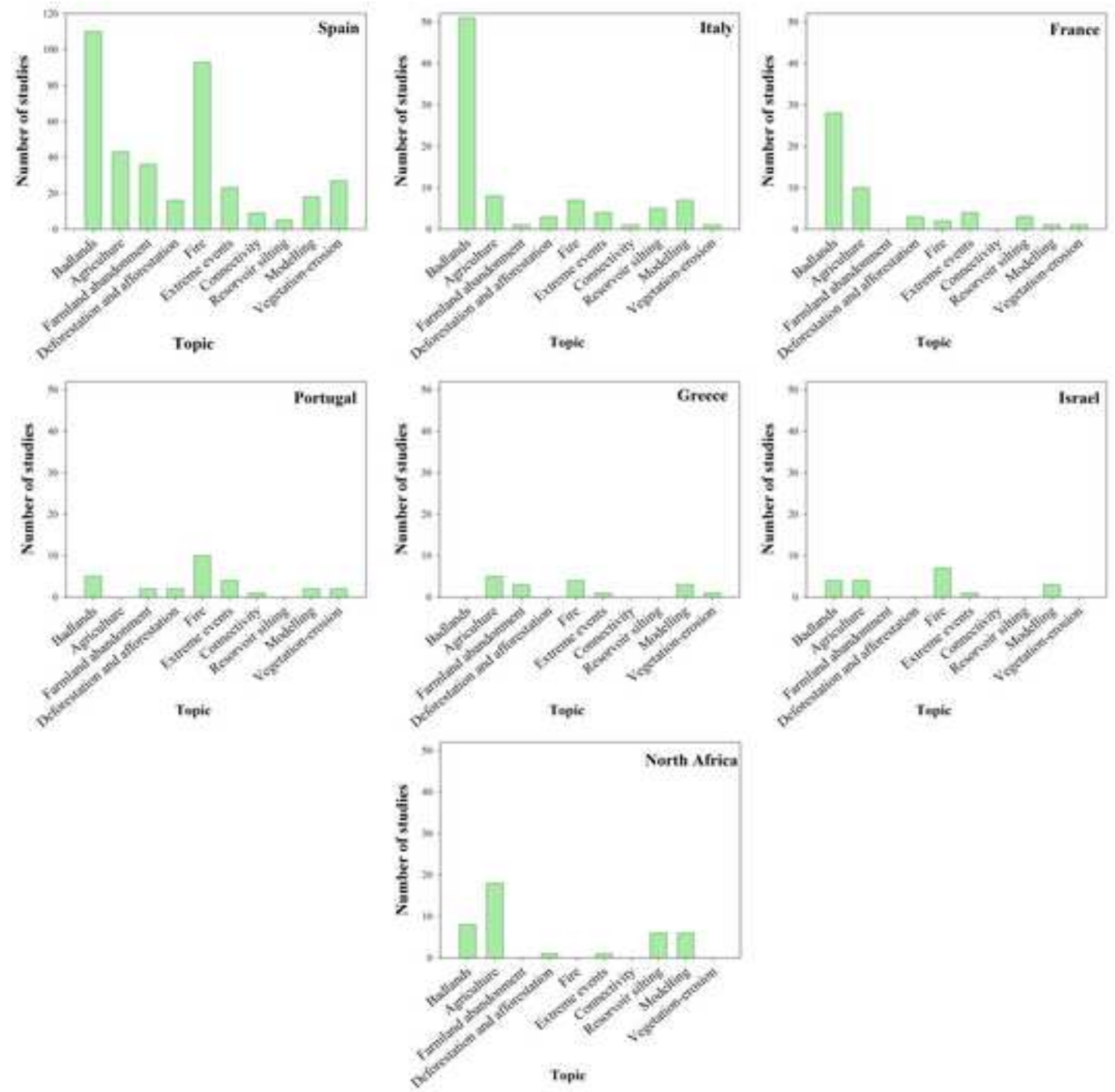


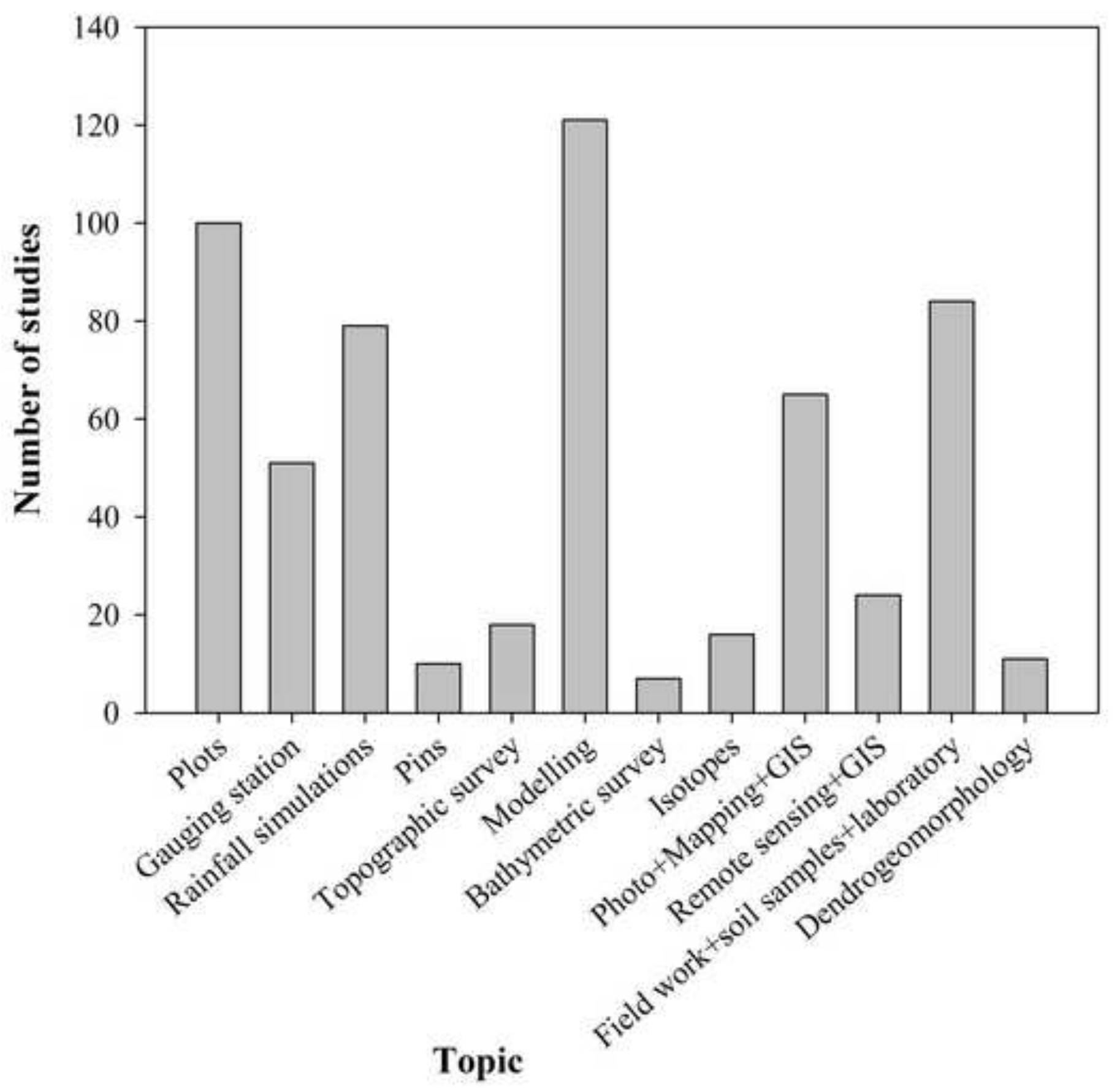




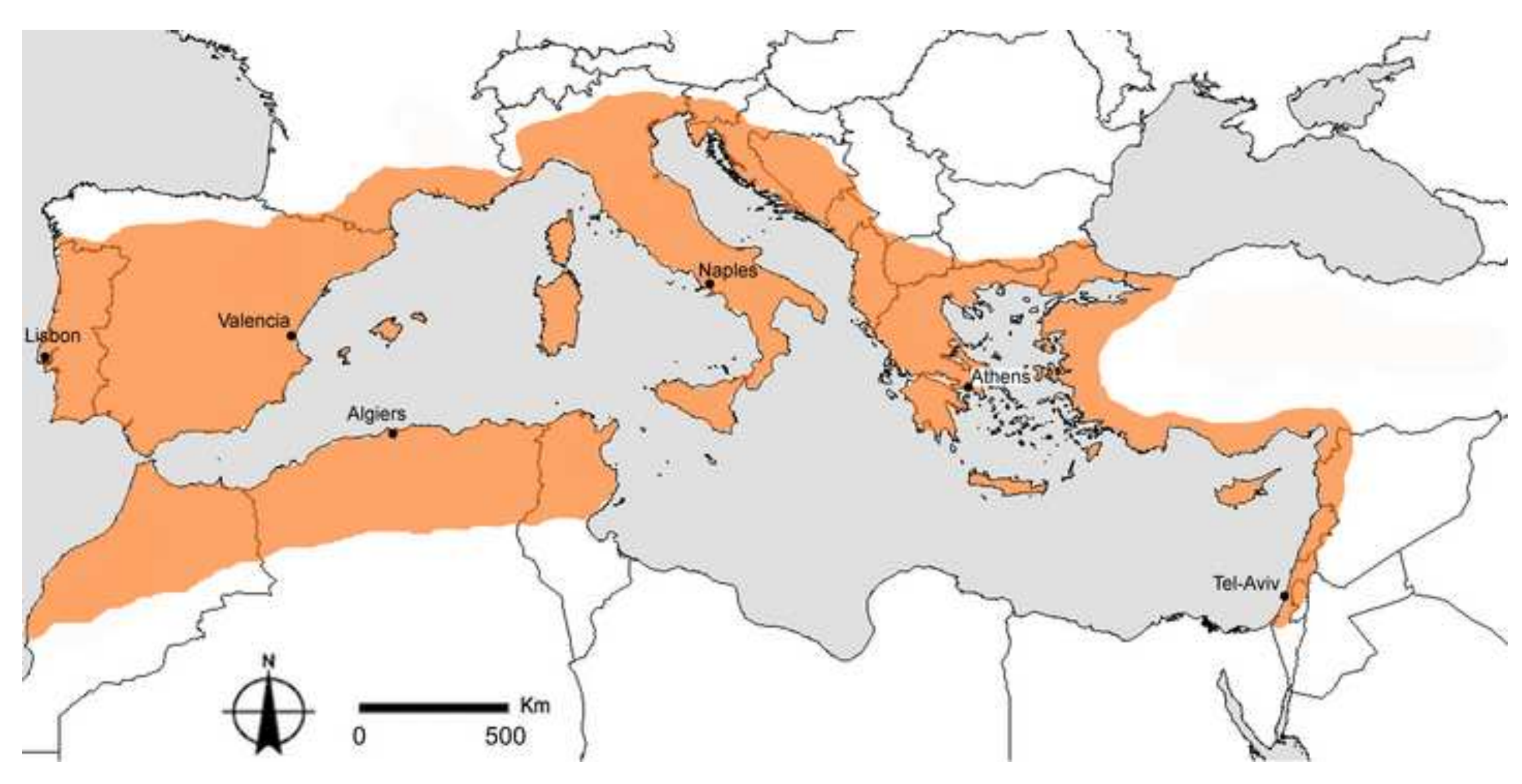



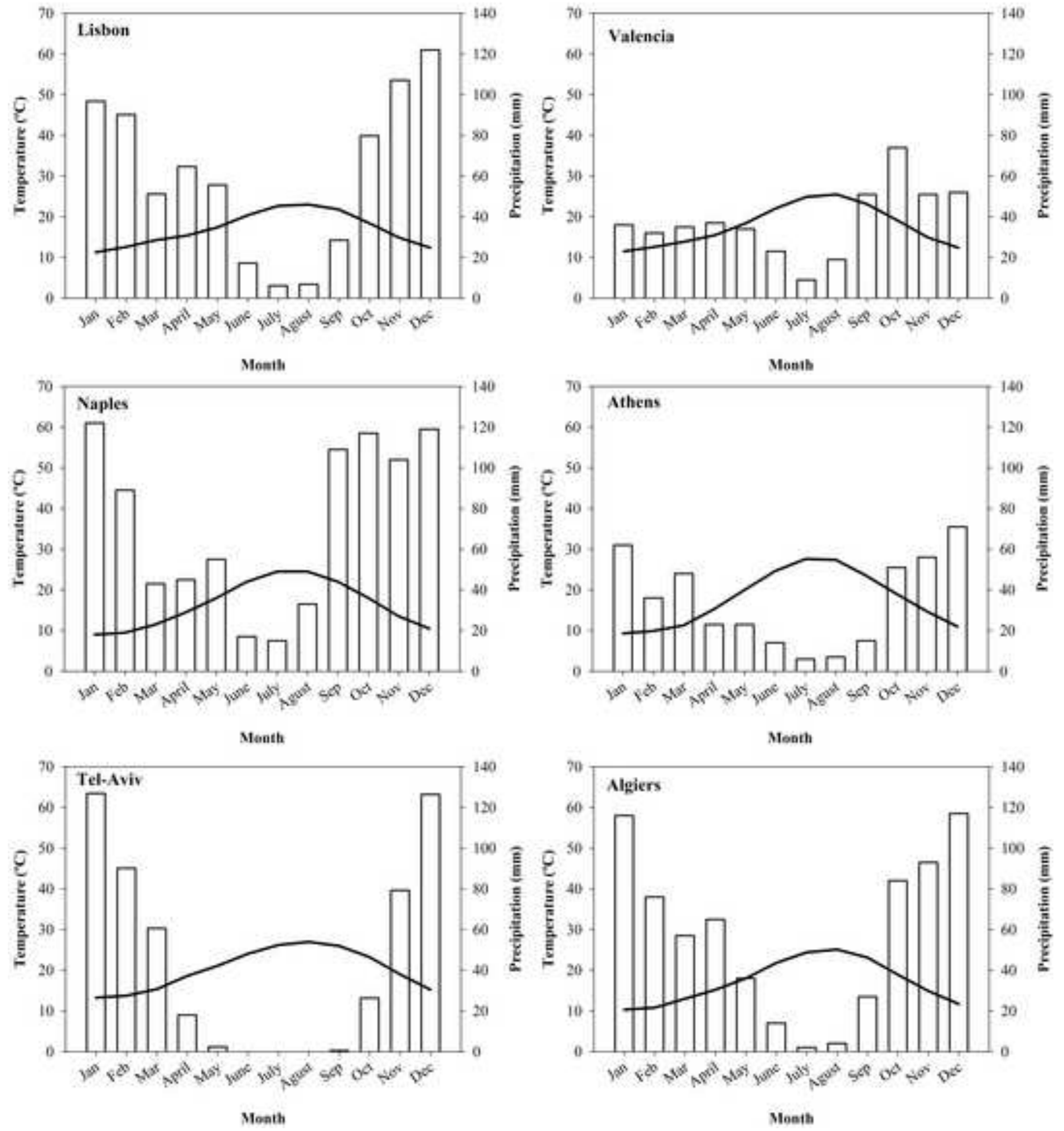
Click here to download high resolution image

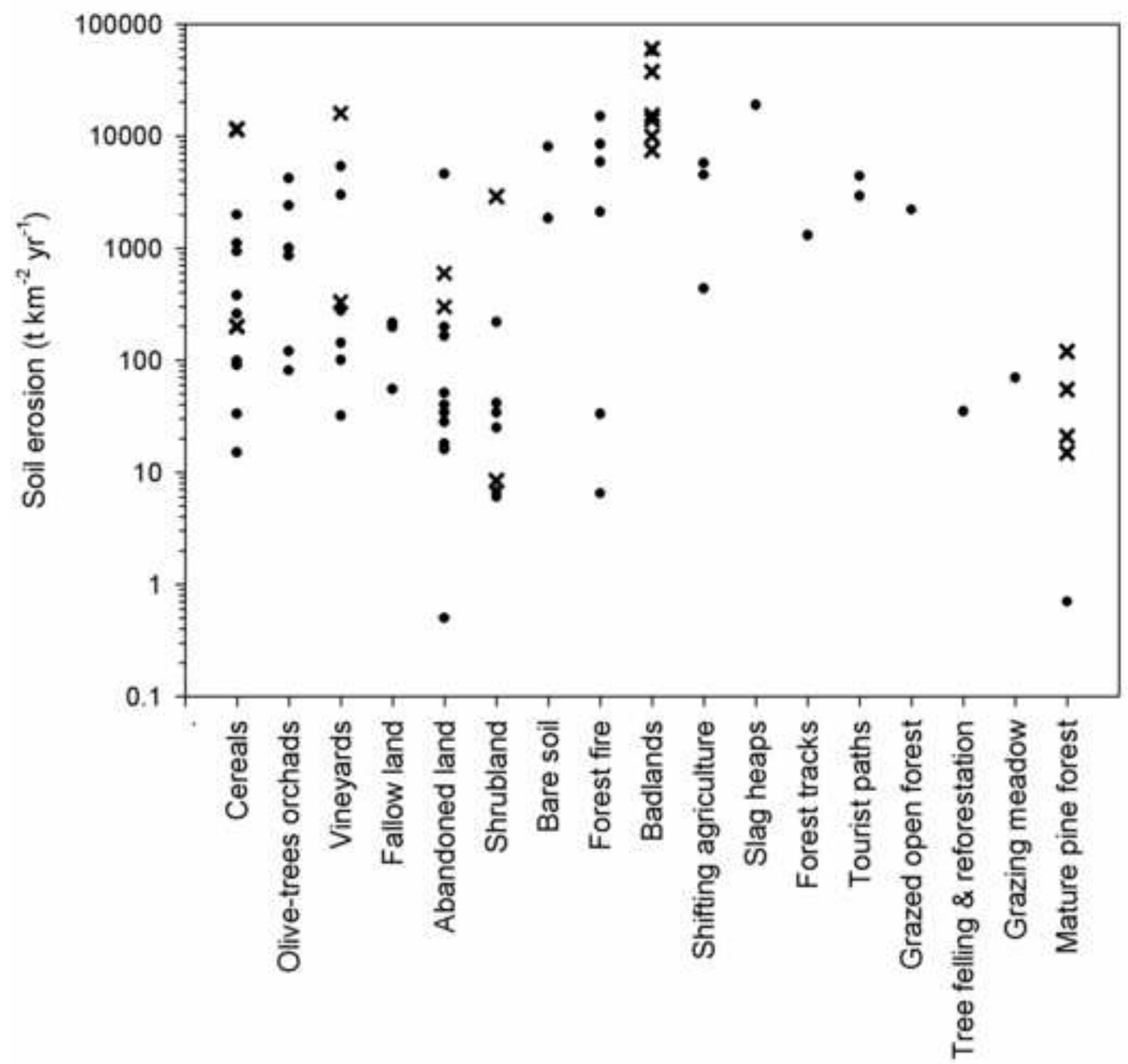

